\title{
How fire safety management attended during the urbanization process in China?
}

DOI:

10.1016/j.jclepro.2019.117686

\section{Document Version}

Accepted author manuscript

Link to publication record in Manchester Research Explorer

\section{Citation for published version (APA):}

Zhang, Y., Shen, L., Ren, Y., \& Wang, J. (2019). How fire safety management attended during the urbanization process in China? Journal of Cleaner Production. https://doi.org/10.1016/j.jclepro.2019.117686

\section{Published in:}

Journal of Cleaner Production

\section{Citing this paper}

Please note that where the full-text provided on Manchester Research Explorer is the Author Accepted Manuscript or Proof version this may differ from the final Published version. If citing, it is advised that you check and use the publisher's definitive version.

\section{General rights}

Copyright and moral rights for the publications made accessible in the Research Explorer are retained by the authors and/or other copyright owners and it is a condition of accessing publications that users recognise and abide by the legal requirements associated with these rights.

\section{Takedown policy}

If you believe that this document breaches copyright please refer to the University of Manchester's Takedown Procedures [http://man.ac.uk/04Y6Bo] or contact uml.scholarlycommunications@manchester.ac.uk providing relevant details, so we can investigate your claim.

\section{OPEN ACCESS}




\section{How fire safety management attended during the urbanization process in China?}

Ying Zhang a, b, Liyin Shen ${ }^{\text {a, b }}$, Yitian Ren ${ }^{\text {a, b* }}{ }^{*}$ Jinhuan Wang a, b, Zhi Liu ${ }^{\text {a b }}$, Hang Yan a, b

a School of Construction Management and Real Estate, Chongqing University, Chongqing, PR China

b International Research Center for Sustainable Built Environment, Chongqing University, Chongqing, PR China

*Corresponding author: Yitian Ren

\section{Highlights:}

- The interrelationship between fire safety management performance and urbanization development in China is investigated.

- Significant variations exist between regions in addressing the fire safety management during urbanization development.

- Policy-recommendations are proposed to enhance fire safety management incorporating most typical urbanization variables.

\footnotetext{
Abstract:

This paper examines how the performance of fire safety management is attended during the dramatic urbanization development process in China. Correlation and regression analysis methods are used to investigate the interrelationship between fire safety management performance and urbanization development. Three indicators are
} 
selected to measure the fire safety management performance, and seventeen indicators are used to measure urbanization development. The data used are collected from 31 provinces in China during 2005-2014. The analysis is conducted at both national and regional levels. The results show that fire safety management has not been well addressed in China although the country has made great progress in its urbanization development. The key attributes to the poor performance of fire safety management include the growth of urban population density, the increase of built-up urban areas, and the lack of fire safety education investment. There are also significant variations between different regions in addressing fire safety management, and the reasons contributing to the differences have been discussed. The findings suggest that tailor-made measures should be implemented in different regions in order to improve the performance of fire safety management throughout the country.

Key words: Fire safety management, sustainable urbanization, fire safety-urbanization interrelationship, correlation and regression analysis, China

\section{Introduction}

The world has witnessed an unprecedented urbanization process in recent decades, and this is particularly the case in large developing countries such as China, which has been making dramatic urbanization development since early 1980s. According to the official statistics, the population urbanization rate of China in the year 1978 was $17.9 \%$, and this figure has increased dramatically to $57.96 \%$ by the year 2017 , which 
is more than three times than the figure in 1978. And the urban population in China has grown from 262.98 million to 803.55 million during 1978-2017 (Word Bank Open Data, 2018). Nevertheless, compared with the urbanization performance in other developed countries worldwide, the urbanization level in China is still relatively low. For example, according to the official statistics, by the year 2017, the population urbanization rate was $92 \%$ in Japan, $83 \%$ in UK, $82 \%$ in USA, $81 \%$ in Canada (World Bank Open Data, 2018). It can be expected that China will continue its ambitious urbanization construction blueprint in the foreseeable future.

The benefits from urbanization have been well appreciated, such as promoting economic development, driving scientific and technological innovation, upgrading industrial structure, and improving people's living quality (Shen et al., 2019; Zhang et al., 2019). And the improvement in fire safety management performance is considered as another important benefit ofLi urbanization development. The experiences in other countries suggest that urbanization development can promote effectively the performance of fire safety management. For example, it was reported that the US government has been emphasizing the improvement of fire safety management performance in the urbanization process through proper fire protection plan and design, and the application of advanced fire safety facilities and fire safety education (Si, 2014).

However, China seems making limited progress in fire safety management during its urbanization process in recent years. According to China Fire Yearbook, the total number of fires in China was 39337 in the year 1994, and this figure was 395052 
in 2014, more than ten times of that in 1994 (Fire Department of the Ministry of Public Security of China, 2015). According to the World Fire Statistics report for the period of 2010-2014, published by international association of fire and rescue service, both the number of annual average fires and the number of annual average fire deaths in China are relatively higher than the other surveyed countries worldwide (World Fire Statistics Report, 2015), as shown in Table 1 and Table 2 respectively.

Table 1 Average number of fires per year in different countries during 2010-2014

\begin{tabular}{c|c}
\hline $\begin{array}{c}\text { Average number of } \\
\text { fires per year }\end{array}$ & $\begin{array}{c}\text { Surveyed Countries } \\
600000-1500000 \\
100000-600000\end{array}$ \\
$\begin{array}{c}\text { USA } \\
20000-100000\end{array}$ & $\begin{array}{r}\text { Japan, Indonesia, Turkey, Canada, South Africa, Malaysia, Netherlands, } \\
\text { Ukraine, Spain, Iran and others }\end{array}$ \\
$10000-20000$ & $\begin{array}{r}\text { Thailand, Algeria, Uzbekistan, Romania, Kazakhstan, Cuba, Czech Republic, } \\
\text { Belgium, Serbia, Denmark, Finland and others }\end{array}$ \\
$5000-10000$ & $\begin{array}{r}\text { Iraq, Shri-Lanka, Syria, Tunis, Slovakia, Georgian, Singapore, Croatia, } \\
\text { Philippine and others }\end{array}$ \\
$<5000$ & $\begin{array}{r}\text { Countries have, as a rule, less than 5thous.fires per year } \\
\hline\end{array}$
\end{tabular}

(Data Source: World Fire Statistics Report)

Table 2 Average number of fire deaths per year in different countries during 2010-2014

\begin{tabular}{cc}
\hline $\begin{array}{c}\text { Average number of } \\
\text { fire deaths per year }\end{array}$ & $\begin{array}{c}\text { Surveyed Countries } \\
10000-25000 \\
1000-10000 \\
200-1000\end{array}$ \\
$\begin{array}{c}\text { India, Russia, Pakistan } \\
\text { USA, China, South African, Ukraine, Japan } \\
\text { Korea, Spain, Poland, Canada, Uzbekistan, Romania, Kazakhstan, } \\
\text { Lithuania, Latvia, Philippine and others. } \\
100-200\end{array}$ \\
Australia, Shri-Lanka, Czechia, Hungary, Sweden, Bulgaria, \\
Moldova and others. \\
Countries have, as a rule, less than 100 fire deaths per year (from 0 to few \\
dozen fire deaths per year)
\end{tabular}

(Data Source: World Fire Statistics Report)

The information in Table 1 and 2 demonstrate the fact that the urbanization 
construction process, which is accompanied by the emergence of skyscrapers, large-scale of underground projects, huge shopping malls and others, has not offered as effective hand rather than a kind of risk to fire safety management in China. Furthermore, there is a rising population shift from rural to urban area in the Chinese urbanization development. According to the official statistics, the floating population in China was 245 million in 2016, whilst the total urban resident population was only 793 million in the same year (China Migrant Population Service Center, 2017). Most of these floating population, with less education and fire safety consciousness, live in poor fire safety conditions and engage in high-fire-risk occupations.

The consequences of fire accidents are severe. For example, in September 2018, the fire occurred in the National Museum of Brazil which has a brilliant history of over 200 years. Nearly 20 million pieces of its collection were devoured by the flames, the damage of which was incalculable for the aspects of social economy, history and culture (News on Phoenix New Media, 2018). For another example, in August 2015, the fire accident occurred in the dangerous goods warehouse in Tianjin Port of China. This fire accident has caused the deaths of 165 people, the injuries of 798 people, the missing of 8 people, the direct economic loss up to 6.866 billion RMB (Baidu News, 2015). In fact, fire accidents can also induce inestimable indirect losses, for example, the air pollution, soil pollution, and water pollution, the influences of which are in a long term (Crippa et al., 2016; Hayasaka et al., 2014; Ovadnevaitė et al., 2006; Ignatavièius et al., 2006; Marlair et al., 2004; Svendsen et al., 1996). Therefore, the importance of raising fire safety management performance is obvious. Good fire 
safety management contributes to providing a safer and cleaner production environment for human activities, which further enables the sustainability of social economic development. Nevertheless, it appears that China is faced with significant challenge in this regard. Although dramatic development in urbanization has been achieved in recent years in the country, there is little understanding on whether and how fire safety management performance has been attended synchronously. In fact, it is expected that the fire safety management should be improved in line with the urbanization development. It is therefore considered important to understand how fire safety management performance in China is associated with its ambitious urbanization program. A proper comprehension on this interrelationship will be able to help formulate strategies of raising fire safety management performance by making use of the opportunity of implementing urbanization.

It appears that China will continue its ambitious urbanization program in the coming future. According to the government work report by China's State Council in 2016, the population urbanization rate will reach $60 \%$ by 2020 (Chinese Government Report, 2016), thus the opportunity of improving fire safety management performance is great in the process of implementing its urbanization plan in China. But this opportunity would be missed without properly understanding the fire safety-urbanization interrelationship. In other words, if the fire safety-urbanization interrelationship is not comprehended, adequate strategies cannot be formulated. Consequently, the fire safety management performance can not be improved in the process of implementing the Chinese urbanization blueprint, which in turn may 
jeopardize the sustainability of urbanization development in the country.

Therefore, this research aims to understand whether or not fire safety management is attended in the urbanization process in China through investigating the fire safety-urbanization interrelationship. The rest of this paper is designed as follows. Section 2 presents a literature review on the research subject of interrelationship between fire safety management performance and urbanization development. Section 3 describes the research method. Section 4 describes the research data processing. Section 5 presents the results and discussion, followed by the conclusion in Section 6 .

\section{Literature Review}

Previous studies have addressed extensively the subjects of urbanization development and fire safety management performance. It is commonly appreciated that urbanization is a process of advancement both socially and economically, which particularly refers to the process of population flow from rural to urban areas (Wang et al., 2019; Ren et al., 2018; Chan and Hu, 2003). Others appreciated that urbanization refers abstract spiritual transformation process in terms of culture, life styles and values (Guan et al., 2018; Shen et al., 2018; Chen et al., 2010; Shen, 2006; Liu and Zhen, 2004). In the existing research, the most popular indicator adopted for measuring the level of urbanization is population urbanization rate, which reflects the level of population urbanization in a given area. In studying urbanization in the context of China, Chen et al. (2010) suggested to measure the urbanization level with considering both population urbanization and land urbanization, as these two aspects 
may not be synchronized in a same area. Others also pointed out the importance of including social-economic and educational perspectives in assessing the urbanization development level in China (Qi et al., 2014; Zhou, 2013; Chen et al., 2009; Yue, 2003).

It was reported in a number of studies that during the process of urbanization, the fire accident has become a more challenging issue and fire losses are increasing rapidly at global level (Si, 2014; Song, 2006; Du et al., 2002; Yang et al., 2002; Wang and Fan, 1997). Scholars have investigated the interrelationship between fire safety and socio-economic development during the process of urbanization development. For example, in early 1970s, Schaeman (1977), Karter et al. (1978) and Jennings (1996) analyzed the interrelationship between fire safety indicators and socio-economic indicators in a group of selected developed countries. Their studies have revealed that the level of economic development has positive impact on the performance of fire safety management. Their studies further show that other socio-economic factors such as educational level, living standard and aging structure of population also have significant influence on fire safety performance. However, in the context of China, the impact of social and economic development on fire safety management seems different from that in international context. By examining statistics, Yang and Jiang (2003) concluded that at national level, the improvement of social economic development does not bring contributions to the performance of fire safety management in China. In studying the interrelationship between social economic development and fire safety management at regional level in China, $\mathrm{Wu}$ et 
al. (2001) and Chen et al. (2007) clustered individual provinces into different groups according to their social-economic development performance, and found that the performance of fire safety management in those advanced regions is poorer than that in those lagged regions.

Other studies have conducted empirical studies to investigate the interrelationship between the performance of fire safety management and urbanization development. For example, Wang et al. (2011) investigated the interrelationship between the number of fires, the direct economic losses of fires, the degree of urbanization and the growth of urbanization in the case cities of Beijing, Hefei, Ji'nan and Changfeng. Their study demonstrates that significant interrelationships exist between these indicators in the surveyed cities. By conducting the regression analysis, Li et al. (2005) concluded that the population urbanization rate in China is positively related to the fire losses. By employing the factor analysis method and correlation analysis, Dong et al. (2015) analyzed the interrelationship between urbanization variables and fire safety variables in referring to Hebei province of China, and found that there is a positive correlation between the level of urbanization and the number of fires.

The above discussion shows that previous researchers have examined extensively fire safety management in relation with urbanization development. However, it appears that little study has been conducted in examining the contribution of urbanization to the improvement of fire safety management in the context of China. Furthermore, limited attention has been given on designing policy instruments for helping improve the performance of fire safety management in urbanization process. 
There is a gap unaddressed whether the performance of fire safety management is properly attended in its dramatic urbanization development process in China. As appreciated in introduction section, urbanization development has been the engine to drive social and economic development in China. The understanding on whether the fast urbanization development in China contributes to the improvement in fire safety management can help both officials and practitioners shape effectively their urbanization mechanism and technologies to ensure that fire safety management can be synchronized along with the urbanization process.

Therefore, this study aims to investigate whether the subject of fire safety management has been attended in implementing the ambitious urbanization program in China. With considering the significant variations in multiple aspects between different regions in China, the empirical study will be conducted at both national and regional level.

\section{Research Method}

\subsection{Research measurements}

To find out whether fire safety management is properly attended in the urbanization process in China by measuring the fire safety-urbanization interrelationships, the research measurement variables need to be defined clearly, including the variables for measuring the level of fire safety management performance, and the variables for measuring the level of urbanization development. 


\section{Variables for measuring the level of fire safety management performance}

Previous studies have presented various variables for measuring the level of fire safety management performance. Based on the research works reviewed in Section 2 (Dong et al., 2015; Yang and Jiang, 2003), three variables are adopted for measuring the level of fire safety management in an urban area, namely, the number of fire $\left(\mathrm{Y}_{1}\right)$, the direct economic loss of fire $\left(\mathrm{Y}_{2}\right)$, and the number of fire casualties $\left(\mathrm{Y}_{3}\right)$.

\section{Variables for measuring the level of urbanization development}

In referring to previous research works on evaluating the urbanization development, as described in Section 2, the level of urbanization development is commonly examined by applying four dimensions of indicators (Qi et al., 2014; Zhou, 2013; Chen et al., 2010), namely, population urbanization, land urbanization, social-economic dimension, and educational dimension. There are various studies about the measurement for these four dimensional urbanization variables, which provide valuable references for formulating evaluation variables in this study (Lv et al., 2016; Guo et al., 2015; Zhou, 2013; Li et al., 2012; Lv et al., 2008; Yang and Jiang, 2003; Yue, 2003). The composition of the indicator system for measuring the level of urbanization development are summarized in Table 3.

Table 3 Variables for measuring the level of urbanization development

\begin{tabular}{c|l|l}
\hline \multirow{2}{*}{ Dimension } & & \multicolumn{1}{|c|}{ Variable } \\
\hline \multirow{3}{*}{$\begin{array}{c}\text { Population } \\
\text { Urbanization }\end{array}$} & $\begin{array}{l}\text { population urbanization rate }\left(\mathrm{X}_{1}\right) \\
\text { (resident population in urban areas/ permanent population) }\end{array}$ & $\%$ \\
\cline { 2 - 3 } & $\begin{array}{l}\text { urban population density }\left(\mathrm{X}_{2}\right) \\
\text { (resident population in urban areas/ urban areas) }\end{array}$ & $10^{4}$ person per $\mathrm{km}^{2}$ \\
\hline
\end{tabular}




\begin{tabular}{|c|c|c|}
\hline & $\begin{array}{l}\text { per capita GDP (Gross Domestic Product) }\left(\mathrm{X}_{3}\right) \\
\text { (regional total GDP / permanent population) }\end{array}$ & $10^{5} \mathrm{Rmb}$ per person \\
\hline \multirow{7}{*}{ Land Urbanization } & areas of completed building $\left(\mathrm{X}_{4}\right)$ & $100 \mathrm{~km}^{2}$ \\
\hline & values of completed building $\left(\mathrm{X}_{5}\right)$ & $10^{8} \mathrm{Rmb}$ \\
\hline & built-up urban areas $\left(\mathrm{X}_{6}\right)$ & $10^{4} \mathrm{~km}^{2}$ \\
\hline & $\begin{array}{l}\text { ratio of built-up urban areas }\left(\mathrm{X}_{7}\right) \\
\text { (built-up urban areas/total land areas in the administrative region) }\end{array}$ & $\%$ \\
\hline & $\begin{array}{l}\text { ratio of construction land }\left(\mathrm{X}_{8}\right) \\
\text { (construction land areas/ total land areas in the administrative region) }\end{array}$ & $\%$ \\
\hline & $\begin{array}{l}\text { utilization rate of construction land }\left(\mathrm{X}_{9}\right) \\
\text { (built-up urban areas/ construction land areas) }\end{array}$ & $\%$ \\
\hline & $\begin{array}{l}\text { the GDP output of per unit land area }\left(\mathrm{X}_{10}\right) \\
\text { (regional total GDP/total land areas in the administrative region) }\end{array}$ & $100 \mathrm{Rmb}$ per $\mathrm{m}^{2}$ \\
\hline \multirow{4}{*}{$\begin{array}{c}\text { Social-economic } \\
\text { Development }\end{array}$} & $\begin{array}{l}\text { total annual savings of urban and rural residents in the administrative region } \\
\left(\mathrm{X}_{11}\right)\end{array}$ & $10^{12} \mathrm{Rmb}$ \\
\hline & $\begin{array}{l}\text { per capita annual savings }\left(\mathrm{X}_{12}\right) \\
\text { (total annual savings of urban and rural residents / permanent population) }\end{array}$ & $10^{4} \mathrm{Rmb}$ per person \\
\hline & $\begin{array}{l}\text { GDP proportion of the second industry }\left(\mathrm{X}_{13}\right) \\
\text { (GDP of the second industry / total regional GDP) }\end{array}$ & $\%$ \\
\hline & $\begin{array}{l}\text { GDP proportion of the third industry }\left(\mathrm{X}_{14}\right) \\
\text { (GDP of the third industry / total regional GDP) }\end{array}$ & $\%$ \\
\hline \multirow{3}{*}{$\begin{array}{l}\text { Educational } \\
\text { Development }\end{array}$} & regional education investment in reported period $\left(\mathrm{X}_{15}\right)$ & $10^{11} \mathrm{Rmb}$ \\
\hline & $\begin{array}{l}\text { proportion of education investment in GDP }\left(\mathrm{X}_{16}\right) \\
\text { (regional education investment / total regional GDP) }\end{array}$ & $\%$ \\
\hline & $\begin{array}{l}\text { percentage of college or above graduates }\left(\mathrm{X}_{17}\right) \\
\text { (number of college or above population /total regional sample population) }\end{array}$ & $\%$ \\
\hline
\end{tabular}

In order to eliminate the influence of magnitude difference and to ensure the accuracy of further analysis, the units of some indicators listed in Table 3 have been adjusted before conducting the following research procedures. As the normalization will not affect the results of independence verification which aims to identify the independent variables for conducting regression analysis, the original research data have not been normalized into $0-1$. 


\subsection{Research Models}

Various methods are available for measuring the fire safety-urbanization interrelationship, including correlation analysis, factor analysis and regression analysis. As a typical factor analysis method, Principle Component Analysis (PCA) is a method to reduce the dimensions of multi indicators by gathering together the indicators which have high correlations into a comprehensive variable (Maitra and Yan, 2008; Li et al., 1999). PCA is commonly used in the cases where multi indicators are needed to be processed. The advantage of factor analysis method is to be able to transform a number of indicators into a few independent comprehensive variables, which are capable to grasp the major information of original indicators. However, the disadvantage of factor analysis method is that it can not help understand the specific meaning of these comprehensive variables and it happens that some useful information may be missed through the process of reducing original indicator dimensions (Maitra and Yan, 2008). Correlation analysis is another effective method to examine the interrelationship between variables by measuring the degree of closeness between the two variables (Cohen et al., 2014; Ezekiel, 1930). Regression analysis is also an effective quantitative method for measuring interrelationship between variables. This method can describe the interrelationship between the dependent and independent variables by regression equations (Cohen et al., 2014; Zhang, 1988; Ezekiel and Fox, 1959), and has been widely adopted in previous studies (Xia et al., 2019; Ince and Aslan, 2019). There are four different types of data in conducting regression analysis, namely, cross-sectional data, time-series data, 
pooled cross-sectional time serious data, and panel data (Baum and Christopher, 2006).

As factor analysis method can not specify the meaning of individual comprehensive variables, the method is considered not suitable in this study, instead, regression analysis method is adopted to investigate the fire safety-urbanization interrelationship in the context of China. In conducting the regression analysis, urbanization development indicators $\left(\mathrm{X}_{\mathrm{i}}\right)$ are defined as independent variables, and fire safety management performance variables $\left(\mathrm{Y}_{\mathrm{j}}\right)$ are defined as dependent variables. Furthermore, the research objects in this study are 31 provinces in China, and the surveyed period is $2005-2014$. This means that each panel only has 31 observations, which is relatively small. Therefore, it is not suitable to use the data as panel data to conduct regression analysis, instead the data is used as pooled cross-sectional time-series data for regression analysis in this study.

In order to avoid the problems of multiple collinear in regression analysis, the correlation analysis should be conducted first to filter out those dependent variables (Ince and Aslan, 2019), and then use the independent variables $\left(\mathrm{X}_{\mathrm{i}}\right)$ to conduct further regression analysis.

\subsubsection{Independence verification}

The following correlation analysis model (1) is used to test the level of independence between two urbanization development variables, namely $X_{R i}$ and $X_{S} i$.

$$
r=\frac{\sum_{i=1}^{n}\left(x_{R i}-\overline{x_{R}}\right)\left(x_{S i}-\overline{x_{S}}\right)}{\sqrt{\sum_{i=1}^{n}\left(x_{R i}-\overline{x_{R}}\right)^{2} \sum_{i=1}^{n}\left(x_{S i}-\overline{x_{S}}\right)^{2}}}
$$


In model (1), $r$ refers to the correlation coefficient between two urbanization variables. According to previous studies (Ezekiel and Fox, 1930), when the value of $r$ is greater than 0.8 (Hou, 2011; Niu et al., 2007; Mathieu et al., 1998) and the value of $P$ is less than 0.05 ( $\mathrm{P}$ value refers to the result of significance test), the two urbanization development variables $\mathrm{X}_{\mathrm{R}}$ and $\mathrm{X}_{\mathrm{S}}$ are appreciated strongly correlated. If the $r$ is smaller than 0.8 , the variables $\mathrm{X}_{\mathrm{R}}$ and $\mathrm{X}_{\mathrm{S}}$ are considered not strongly correlated. And the independence verification is conducted by examining the correlations between all explanatory variables instead of pair-wise comparison. The variables correlated with more other variables, or the variables which has no strong correlation with other variables will be identified and selected as independent and representative variables for further regression analysis.

\subsubsection{Regression analysis model}

After selecting the independent urbanization development variables $\mathrm{X}_{\mathrm{i}}$, the multiple linear regression model is applied to analyze the interrelationship between the fire safety management indicators $Y_{j}$ and the urbanization indicators $X_{i}$ by referring to the following model (2):

$$
y_{i}=b_{0}+b_{1} x_{1}+b_{2} x_{2}+b_{3} x_{3}+\cdots+b_{i} x_{i}+\varepsilon
$$

In model (2), $y_{i}$ is defined as dependent variable for measuring the level of fire safety management performance, $x_{i}$ is an independent urbanization development variable, and $\varepsilon$ is the random error term. $b_{0}$ is a constant, and the parameters, $b_{1}$, $b_{2}, \ldots, b_{i}$ are the regression coefficients for individual urbanization development 
variables $x_{i}$ (Ezekiel and Fox, 1959).

\section{Data Processing}

In referring to the indicator systems described in Table 3, the research data for the indicators are collected and processed.

\subsection{Data Collection}

The data used for analysis in this study are from three types of sources, namely, National Bureau of Statistics of the People's Republic of China (China Statistical Yearbook, 2005-2014), CSMAR Research Data Service, and China Fire Yearbook. The data cover the surveyed period from 2005 to 2014 for all the 31 provincial administrative units in China. Due to the absence of the census in 2010, default processing for relevant data has been conducted. Table 4 presents the statistical description of the origin research data. 
Table 4 The statistical description of research data

\begin{tabular}{|c|c|c|c|c|c|c|c|}
\hline & Variable & Unit & Obs & Mean & Std. Dev. & Min & Max \\
\hline $\mathrm{X}_{1}$ & population urbanization rate & $\%$ & 310 & 0.5029 & 0.1486 & 0.2071 (Tibet) & 0.8961 (Shanghai) \\
\hline $\mathrm{X}_{2}$ & urban population density & $10^{4}$ person per $\mathrm{km}^{2}$ & 310 & 0.2613 & 0.1339 & 0.0189(Ningxia) & 0.6307 (Shannxi) \\
\hline $\mathrm{X}_{3}$ & per capita GDP & $10^{5} \mathrm{Rmb}$ per person & 310 & 0.3256 & 0.2038 & 0.0505 (Guizhou) & 1.0523 (Tianjin) \\
\hline $\mathrm{X}_{5}$ & values of completed building & $10^{8} \mathrm{Rmb}$ & 310 & 1.2801 & 1.1967 & 0.0286(Tibet) & 7.4050 (Jiangsu) \\
\hline $\mathrm{X}_{6}$ & built-up urban areas & $10^{4} \mathrm{~km}^{2}$ & 307 & 0.1312 & 0.1003 & 0.0075 (Tibet) & 0.5398 (Guangdong) \\
\hline $\mathrm{X}_{9}$ & utilization rate of construction land & $\%$ & 309 & 0.1249 & 0.0757 & 0.0331(Qinghai) & 0.3962 (Beijing) \\
\hline $\mathrm{X}_{10}$ & the GDP output of per unit land area & $10^{2} \mathrm{Rmb}$ per $\mathrm{m}^{2}$ & 308 & 0.2139 & 0.5025 & 0.0002 (Tibet) & 3.7170 (Shanghai) \\
\hline $\mathrm{X}_{11}$ & total annual savings of urban and rural residents in the & $10^{12} \mathrm{Rmb}$ & 310 & 0.9424 & 0.8651 & 0.0123 (Tibet) & 5.2411(Guangdong) \\
\hline
\end{tabular}


administrative region

$\mathrm{X}_{12} \quad$ per capita annual savings
$\mathrm{X}_{13} \quad$ GDP proportion of the second industry
$\mathrm{X}_{14} \quad$ GDP proportion of the third industry
$\mathrm{X}_{15} \quad$ regional education investment in reported period
$\mathrm{X}_{16} \quad$ proportion of education investment in GDP
$\mathrm{X}_{17} \quad$ percentage of college or above graduates
$\mathrm{Y}_{1} \quad$ the number of fires
$\mathrm{Y}_{2} \quad$ the direct economic loss of fires
$\mathrm{Y}_{3} \quad$ the number of fire casualties

$\begin{array}{cccccc}10^{4} \mathrm{Rmb} \text { per person } & 310 & 2.2946 & 1.7661 & 0.3622 \text { (Guizhou) } & 11.2260 \text { (Beijing) } \\ \% & 310 & 0.4722 & 0.0806 & 0.2131 \text { (Shanxi) } & 0.5905 \text { (Beijing) } \\ \% & 310 & 0.4135 & 0.0854 & 0.2830 \text { (Henan) } & 0.7795 \text { (Beijing) } \\ 10^{11} \mathrm{Rmb} & 310 & 0.5695 & 0.4402 & 0.0277 \text { (Tibet) } & 2.7357 \text { (Guangdong) } \\ \% & 310 & 0.0503 & 0.0206 & 0.0248 \text { (Shandong) } & 0.1661 \text { (Tibet) } \\ \% & 279 & 0.0939 & 0.0623 & 0.0089 \text { (Tibet) } & 0.4121 \text { (Beijing) } \\ 10^{4} \text { fire } & 310 & 0.6715 & 0.6328 & 0.0105 \text { (Tibet) } & 4.6141 \text { (Zhejiang) } \\ 10^{8} \text { Rmb } & 310 & 0.7246 & 0.7623 & 0.0238 \text { (Ningxia) } & 5.6716 \text { (Zhejiang) } \\ 10^{3} \text { person } & 310 & 0.0867 & 0.0768 & 0.0010 \text { (Ningxia) } & 0.6480 \text { (Guangdong) }\end{array}$




\subsection{Independence test of urbanization variables $\left(\mathrm{X}_{\mathrm{i}}\right)$}

By using the data described in Section 4.1, and in referring to the model (1) defined in Section 3, the correlation analysis on the urbanization development variables $\mathrm{X}_{\mathrm{i}}$ is conducted with the assistance of the software STATA. The results are shown in Table 5. There are two values in each box in the table. The first value is the correlation coefficient ( $r$ ) of the two corresponding variables, and the second value is the $p$-value in the T-test. In referring to the selection principle described in methodology section, the variables correlated with more other variables, and the variables which have no strong correlation with all the other variables are identified and used as representative variables for further regression analysis in this study.

For example, it can be seen in Table 5 that $\mathrm{X}_{1}$ (the population urbanization rate) has strong correlation with four variables $\left(\mathrm{X}_{3}, \mathrm{X}_{9}, \mathrm{X}_{12}, \mathrm{X}_{17}\right)$, which is the highest in terms of the number of correlated variables. Therefore, $X_{1}$ is kept and used for conducting further regression analysis. By conducting similar analysis, $\mathrm{X}_{5}$ (values of completed building) and $\mathrm{X}_{7}$ (the proportion of built-up areas) are also identified and used. On the other hand, $\mathrm{X}_{2}$ (urban population density), $\mathrm{X}_{13}$ (GDP proportion of second industry), $\mathrm{X}_{14}$ (GDP proportion of third industry) and $\mathrm{X}_{16}$ (proportion of education investment in GDP) have no strong correlation with all the other variables, thus they are kept as independent variables. Following this analysis, variable $\mathrm{X}_{1}, \mathrm{X}_{2}, \mathrm{X}_{5}, \mathrm{X}_{7}, \mathrm{X}_{13}, \mathrm{X}_{14}$ and $\mathrm{X}_{16}$ are selected as independent and representative variables for further regression analysis, whilst $\mathrm{X}_{3}, \mathrm{X}_{4}, \mathrm{X}_{6}, \mathrm{X}_{8}, \mathrm{X}_{9}, \mathrm{X}_{10}, \mathrm{X}_{11}, \mathrm{X}_{12}, \mathrm{X}_{15}$ and $\mathrm{X}_{17}$ are removed. 
Table 5 Results of independence test between urbanization variables $\left(\mathrm{X}_{\mathrm{i}}\right)$

\begin{tabular}{|c|c|c|c|c|c|c|c|c|c|c|c|c|c|c|c|c|c|c|}
\hline & Variable & $\mathrm{X}_{1}$ & $\mathrm{X}_{2}$ & $\mathrm{X}_{3}$ & $\mathrm{X}_{4}$ & $\mathrm{X}_{5}$ & $\mathrm{X}_{6}$ & $\mathrm{X}_{7}$ & $\mathrm{X}_{8}$ & $\mathrm{X}_{9}$ & $\mathrm{X}_{10}$ & $\mathrm{X}_{11}$ & $\mathrm{X}_{12}$ & $\mathrm{X}_{13}$ & $\mathrm{X}_{14}$ & $\mathrm{X}_{15}$ & $\mathrm{X}_{16}$ & $\mathrm{X}_{17}$ \\
\hline $\mathrm{X}_{1}$ & $\begin{array}{l}\text { population urbanization } \\
\text { rate }\end{array}$ & 1.0000 & & & & & & & & & & & & & & & & \\
\hline \multirow[t]{2}{*}{$\mathrm{X}_{2}$} & urban population density & -0.1280 & & & & & & & & & & & & & & & & \\
\hline & & 0.0243 & 1.0000 & & & & & & & & & & & & & & & \\
\hline \multirow[t]{2}{*}{$\mathrm{X}_{3}$} & per capita GDP(Gross & 0.8487 & -0.0928 & & & & & & & & & & & & & & & \\
\hline & Domestic Product) & 0.0000 & 0.1031 & 1.0000 & & & & & & & & & & & & & & \\
\hline \multirow[t]{2}{*}{$\mathrm{X}_{4}$} & areas of completed & 0.0628 & 0.0465 & 0.2032 & 10000 & & & & & & & & & & & & & \\
\hline & building & 0.2700 & 0.4148 & 0.0003 & 1.0000 & & & & & & & & & & & & & \\
\hline \multirow[t]{2}{*}{$\mathrm{X}_{5}$} & values of completed & 0.3199 & -0.0167 & 0.4958 & 0.8806 & & & & & & & & & & & & & \\
\hline & building & 0.0000 & 0.7700 & 0.0000 & 0.0000 & 1.0000 & & & & & & & & & & & & \\
\hline \multirow[t]{2}{*}{$\mathrm{X}_{6}$} & built-up urban areas & 0.3215 & -0.0641 & 0.3532 & 0.8135 & 0.8348 & 10000 & & & & & & & & & & & \\
\hline & & 0.0000 & 0.2625 & 0.0000 & 0.0000 & 0.0000 & 1.0000 & & & & & & & & & & & \\
\hline \multirow[t]{2}{*}{$\mathrm{X}_{7}$} & ratio of built-up urban & 0.7884 & -0.0289 & 0.6849 & -0.0130 & 0.1644 & 0.1516 & \multirow{2}{*}{1.0000} & & & & & & & & & & \\
\hline & areas & 0.0000 & 0.6144 & 0.0000 & 0.8200 & 0.0039 & 0.0080 & & & & & & & & & & & \\
\hline \multirow[t]{2}{*}{$\mathrm{X}_{8}$} & ratio of construction land & 0.7648 & -0.0216 & 0.6871 & 0.1955 & 0.3206 & 0.2814 & 0.9072 & \multirow{2}{*}{1.0000} & & & & & & & & & \\
\hline & & 0.0000 & 0.7061 & 0.0000 & 0.0006 & 0.0000 & 0.0000 & 0.0000 & & & & & & & & & & \\
\hline \multirow[t]{2}{*}{$\mathrm{X}_{9}$} & utilization rate of & 0.8278 & -0.1707 & 0.7102 & 0.0812 & 0.2858 & 0.3543 & 0.8556 & 0.7259 & \multirow{2}{*}{1.0000} & & & & & & & & \\
\hline & construction land & 0.0000 & 0.0026 & 0.0000 & 0.1546 & 0.0000 & 0.0000 & 0.0000 & 0.0000 & & & & & & & & & \\
\hline \multirow[t]{2}{*}{$\mathrm{X}_{10}$} & the GDP output of per & 0.7015 & 0.0359 & 0.6781 & -0.0398 & 0.1407 & 0.0888 & 0.9530 & 0.8592 & 0.7411 & \multirow{2}{*}{1.0000} & & & & & & & \\
\hline & unit land area & 0.0000 & 0.5300 & 0.0000 & 0.4856 & 0.0133 & 0.1210 & 0.0000 & 0.0000 & 0.0000 & & & & & & & & \\
\hline
\end{tabular}


total annual savings of

\begin{tabular}{ll|llllllllll}
$\mathrm{X}_{11}$ & urban and rural residents & 0.4604 & 0.0021 & 0.5813 & 0.7087 & $\mathbf{0 . 8 7 0 8}$ & $\mathbf{0 . 8 7 5 2}$ & 0.3235 & 0.3856 & 0.5040 & 0.3112
\end{tabular}

in the administrative

$\begin{array}{lllllllllll}0.0000 & 0.9702 & 0.0000 & 0.0000 & \mathbf{0 . 0 0 0 0} & \mathbf{0 . 0 0 0 0} & 0.0000 & 0.0000 & 0.0000 & 0.0000\end{array}$

1.0000

region

$\begin{array}{llllllllllllll}\mathrm{X}_{12} & \text { per capita annual savings } & \mathbf{0 . 8 3 8 1} & -0.0570 & \mathbf{0 . 8 9 7 2} & 0.0681 & 0.3524 & 0.2607 & 0.7548 & 0.6602 & \mathbf{0 . 8 2 2 1} & 0.7271 & 0.5586\end{array}$

$\begin{array}{llllllllllll}\mathbf{0 . 0 0 0 0} & 0.3175 & \mathbf{0 . 0 0 0 0} & 0.2316 & 0.0000 & 0.0000 & 0.0000 & 0.0000 & \mathbf{0 . 0 0 0 0} & 0.0000 & 0.0000\end{array}$

1.0000

$\mathrm{X}_{13}$ GDP proportion of the second industry

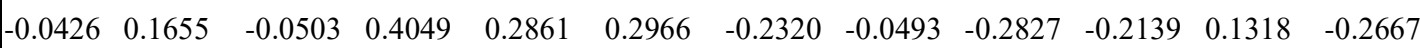

$\begin{array}{lllllllllllll}0.4546 & 0.0035 & 0.3775 & 0.0000 & 0.0000 & 0.0000 & 0.0000 & 0.3882 & 0.0000 & 0.0002 & 0.0203 & 0.0000\end{array}$

1.0000

$\mathrm{X}_{14}$ GDP proportion of the third industry

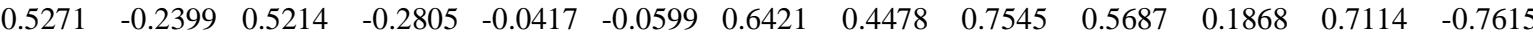

$\begin{array}{lllllllllllllll}0.0000 & 0.0000 & 0.0000 & 0.0000 & 0.4649 & 0.2952 & 0.0000 & 0.0000 & 0.0000 & 0.0000 & 0.0009 & 0.0000 & 0.0000 & 1.0000\end{array}$

$\mathrm{X}_{15}$ regional education

investment in reported period

$\mathrm{X}_{16}$ proportion of education investment in GDP

$\begin{array}{llllllllllllll}0.3335 & 0.0797 & 0.5245 & 0.7791 & \mathbf{0 . 9 0 5 4} & \mathbf{0 . 8 4 2 0} & 0.2004 & 0.2941 & 0.3581 & 0.2034 & \mathbf{0 . 9 4 9 7} & 0.4408 & 0.1944 & 0.0557\end{array}$

$\begin{array}{llllllllllllllll}0.0000 & 0.1617 & 0.0000 & 0.0000 & \mathbf{0 . 0 0 0 0} & \mathbf{0 . 0 0 0 0} & 0.0004 & 0.0000 & 0.0000 & 0.0003 & \mathbf{0 . 0 0 0 0} & 0.0000 & 0.0006 & 0.3281\end{array}$

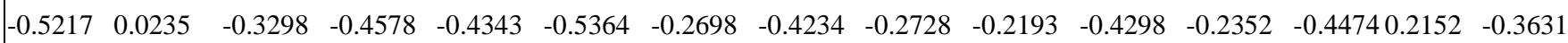

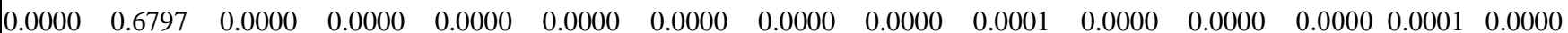

$\mathrm{X}_{17}$ percentage of college or

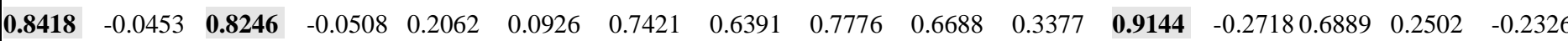
above graduates

$\begin{array}{lllllllllllllllll}\mathbf{0 . 0 0 0 0} & 0.4512 & \mathbf{0 . 0 0 0 0} & 0.3982 & 0.0005 & 0.1243 & 0.0000 & 0.0000 & 0.0000 & 0.0000 & 0.0000 & \mathbf{0 . 0 0 0 0} & 0.0000 & 0.0000 & 0.0000 & 0.0001\end{array}$ 


\section{Results and discussion}

\subsection{Analysis results}

\subsubsection{Interrelationships between $\mathrm{Xi}$ and $\mathrm{Yj}$ at national level}

According to model (2), regression analysis is conducted between the seven independent variables $\left(\mathrm{X}_{1}, \mathrm{X}_{2}, \mathrm{X}_{5}, \mathrm{X}_{7}, \mathrm{X}_{13}, \mathrm{X}_{14}\right.$ and $\left.\mathrm{X}_{16}\right)$ and the three dependent variables $\left(\mathrm{Y}_{1}, \mathrm{Y}_{2}\right.$ and $\left.\mathrm{Y}_{3}\right)$. The analysis results are demonstrated in Table 6 .

Table 6 Regression analysis results between $\mathrm{X}$ and $\mathrm{Y}$ at national level

\begin{tabular}{|c|c|c|c|}
\hline Urbanization Variables safety management & $\mathrm{Y}_{1}$ & $\mathrm{Y}_{2}$ & $\mathrm{Y}_{3}$ \\
\hline $\mathrm{X}_{1}$ & $0.6387(0.4662)$ & $1.0102 *(0.5312)$ & $-0.1212 *(0.0625)$ \\
\hline $\mathrm{X}_{2}$ & $-0.1754(0.2301)$ & $0.7837 * * *(0.2622)$ & $-0.0635 * *(0.0309)$ \\
\hline $\mathrm{X}_{5}$ & $0.2786 * * *(0.0277)$ & $0.4245 * * *(0.0316)$ & $0.0232 * * *(0.0037)$ \\
\hline $\mathrm{X}_{7}$ & $-5.3487 * * *(1.8403)$ & $-6.3929 * * *(2.0966)$ & $-0.0476(0.2467)$ \\
\hline $\mathrm{X}_{13}$ & $-0.7999(0.7823)$ & $-0.7596(0.8913)$ & $-0.0151(0.1049)$ \\
\hline $\mathrm{X}_{14}$ & $0.2652(1.0258)$ & $0.6279(1.1687)$ & $0.2566 *(0.1375)$ \\
\hline $\mathrm{X}_{16}$ & $-5.2404 * *(2.3442)$ & $1.9314(2.6707)$ & $-1.2338 * * *(0.3143)$ \\
\hline $\mathrm{b}_{0}$ & $0.6642(0.6368)$ & $-0.4195(0.7254)$ & $0.0991(0.0854)$ \\
\hline$N$ & 307 & 307 & 307 \\
\hline Adjusted R ${ }^{2}$ & 0.3644 & 0.4327 & 0.2252 \\
\hline $\mathrm{F}$ & 26.0671 & 34.3447 & 13.7033 \\
\hline Prob $>P$ & 0.0000 & 0.0000 & 0.0000 \\
\hline
\end{tabular}

Table note:

(1) * indicates that $p$-value of the coefficient is in the range from 0.05 to $0.1, * *$ indicating a $p$-value of 0.01 to 0.05 , and $* * *$ with the $p$-value of less than 0.01 .

(2) The number within the bracket is the standard error of the coefficient.

According to previous studies, it is generally considered that the regression result between two variables is valid only if the p-value in the T-test is less than 0.05 . As a result, the regression coefficients marked with $* *$ or $* * *$ in Table 6 are kept and 
used for further discussion. The other coefficients are discarded. The corresponding value $" \mathrm{~b}_{0}$ " in the table is the constant of the regression equation. $\mathrm{N}$ represents the number of data sets, namely, 307 in this study. Adjusted $\mathrm{R}^{2}$ indicates the goodness of fit test of the regression equation, which is between the interval " $0-1$ ". $F$ is the result of the F-test of the regression equation, and Prob $>\mathrm{F}$ refers to the $p$-value in the F-test of the equation, which should be less than 0.05 , if the regression equation is considered valid (Ezekiel and Fox, 1959).

\subsubsection{Interrelationships between $X_{i}$ and $Y_{j}$ at regional level}

The regression analysis results in the Section 5.1 are about the fire safety-urbanization interrelationship at national level. However, it is important to analyze the interrelationship at regional level as well, because there are significant variations between regions across multiple aspects. China's territory is so vast that the development at provincial and regional level is extremely unbalanced. For instance, the value of per capita GDP in 2014 spreads between 105,230 Rmb (the highest of Tianjin) and 26,430 Rmb (the lowest of Gansu) among individual provinces (National Bureau of Statistics of China, 2015). According to the regional division defined by National Bureau of Statistics, the 31 provincial administrative units in China are divided into four parts, namely the Eastern, Central, Western and Northeast China, as presented in Figure 1. 


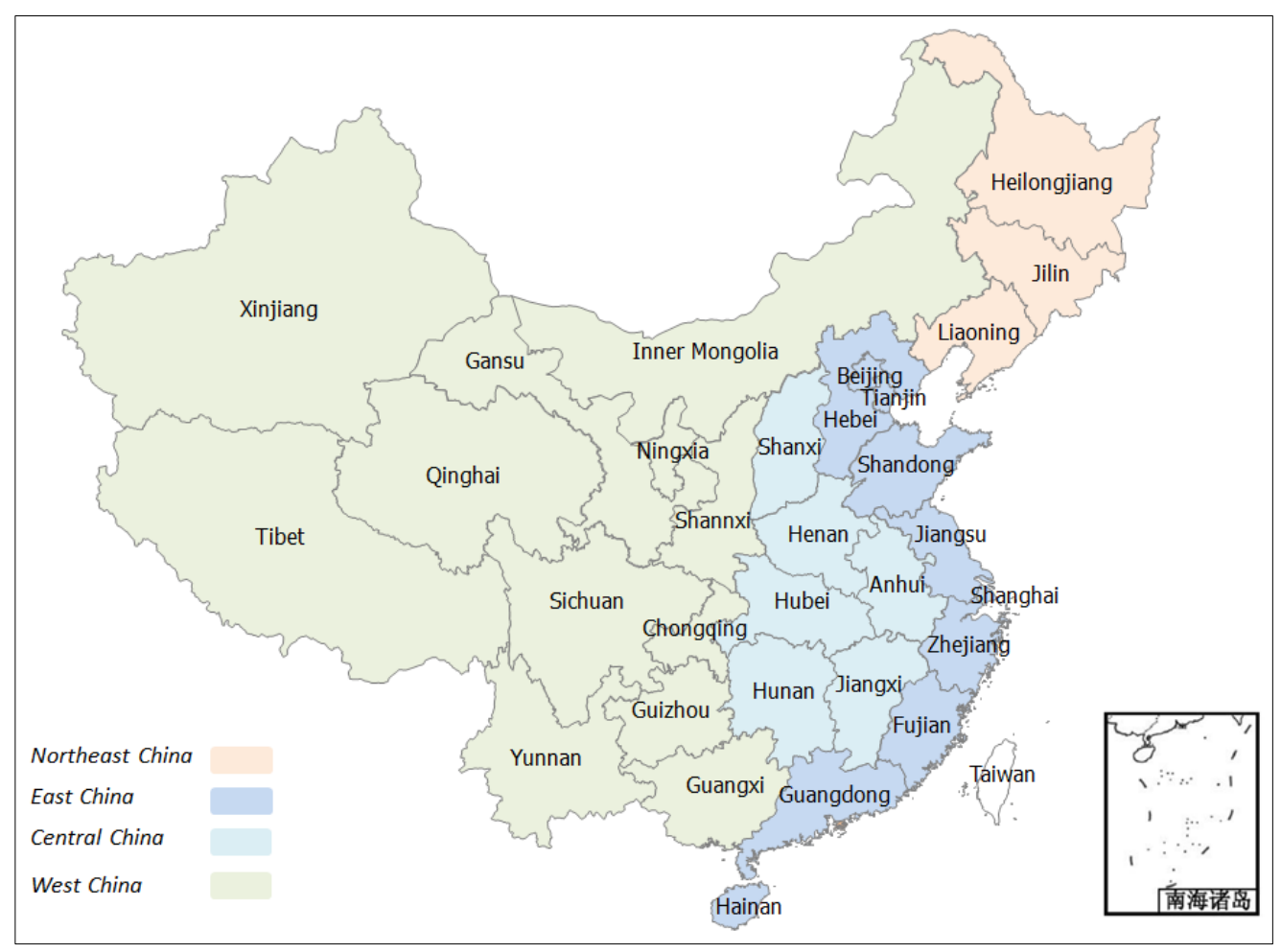

Figure 1 Geographic division of four regions in China

East China includes 10 provincial administrative units, including Beijing, Tianjin, Hebei, Shanghai, Jiangsu, Zhejiang, Fujian, Shandong, Guangdong, and Hainan. Central China includes 6 provincial administrative units, namely Shanxi, Anhui, Jiangxi, Henan, Hubei and Hunan. Furthermore, the West China is composed of the following 12 provinces like Guangxi, Chongqing, Sichuan, Guizhou, Yunnan, Tibet, Shaanxi, Gansu, Qinghai, Ningxia, Inner Mongolia and Xinjiang. And the Northeast region includes Liaoning, Jilin and Heilongjiang.

It is commonly appreciated that the Eastern China is the most developed region in the country, evidenced by the total GDP in 2016 is 41,019 billion Rmb in this region, whilst this figure is about 16,065 and 15,683 billion Rmb in Middle and West China respectively (National Bureau of Statistics of China, 2017). It is therefore important to 
understand whether and how different in terms of fire safety-urbanization interrelationship between these regions.

By applying the research data described in Section 4 to the model (2), with the assistance of STATA software, the regression analysis results for the fire safety-urbanization interrelationship of the four regions can be obtained, as shown in Table 7. 
Table 7 Regression analysis results on fire safety-urbanization interrelationship at regional level

\begin{tabular}{|c|c|c|c|c|c|c|c|c|c|c|c|c|}
\hline & \multicolumn{3}{|c|}{ Eastern China } & \multicolumn{3}{|c|}{ Central China } & \multicolumn{3}{|c|}{ West China } & \multicolumn{3}{|c|}{ Northeast China } \\
\hline & $\mathrm{Y}_{1}$ & $\mathrm{Y}_{2}$ & $\mathrm{Y}_{3}$ & $\mathrm{Y}_{1}$ & $\mathrm{Y}_{2}$ & $\mathrm{Y}_{3}$ & $\mathrm{Y}_{1}$ & $\mathrm{Y}_{2}$ & $\mathrm{Y}_{3}$ & $\mathrm{Y}_{1}$ & $\mathrm{Y}_{2}$ & $\mathrm{Y}_{3}$ \\
\hline $\mathrm{X}_{1}$ & $\begin{array}{l}-0.9838 \\
(1.6855)\end{array}$ & $\begin{array}{l}-1.0398 \\
(2.0160)\end{array}$ & $\begin{array}{l}-0.1525 \\
(0.2363)\end{array}$ & $\begin{array}{l}-0.4816 \\
(1.4902)\end{array}$ & $\begin{array}{l}-0.0674 \\
(1.8974)\end{array}$ & $\begin{array}{c}-0.6999 * * * \\
(0.1543)\end{array}$ & $\begin{array}{c}1.7492 * * * \\
(0.5884)\end{array}$ & $\begin{array}{c}2.4557 * * * \\
(0.8700)\end{array}$ & $\begin{array}{l}-0.0928 \\
(0.0845)\end{array}$ & $\begin{array}{c}-1.0243 \\
(11.2054)\end{array}$ & $\begin{array}{l}-1.2535 \\
(8.5036)\end{array}$ & $\begin{array}{c}1.2560 \\
(1.0671)\end{array}$ \\
\hline $\mathrm{X}_{2}$ & $\begin{array}{l}-1.2121 \\
(1.3918)\end{array}$ & $\begin{array}{c}4.2698 * * \\
(1.6648)\end{array}$ & $\begin{array}{c}0.2471 \\
(0.1951)\end{array}$ & $\begin{array}{c}0.1610 \\
(0.5373)\end{array}$ & $\begin{array}{c}0.7144 \\
(0.6841)\end{array}$ & $\begin{array}{c}-0.1084 * \\
(0.0556)\end{array}$ & $\begin{array}{c}0.2530 \\
(0.1632)\end{array}$ & $\begin{array}{c}0.7718^{* * * *} \\
(0.2413)\end{array}$ & $\begin{array}{l}-0.0235 \\
(0.0234)\end{array}$ & $\begin{array}{c}-4.5463^{* * * *} \\
(1.4505)\end{array}$ & $\begin{array}{l}-0.3100 \\
(1.1008)\end{array}$ & $\begin{array}{l}-0.1569 \\
(0.1381)\end{array}$ \\
\hline $\mathrm{X}_{5}$ & $\begin{array}{c}0.3293 * * * \\
(0.0500)\end{array}$ & $\begin{array}{c}0.4657 * * * \\
(0.0599)\end{array}$ & $\begin{array}{c}0.0245 * * * \\
(0.0070)\end{array}$ & $\begin{array}{c}0.2459 \\
(0.1525)\end{array}$ & $\begin{array}{c}0.6530 * * * \\
(0.1941)\end{array}$ & $\begin{array}{c}0.0496 * * * \\
(0.0158)\end{array}$ & $\begin{array}{c}0.3080 * * * \\
(0.0437)\end{array}$ & $\begin{array}{c}0.4392 * * * \\
(0.0646)\end{array}$ & $\begin{array}{c}0.0221 * * * \\
(0.0063)\end{array}$ & $\begin{array}{c}0.3830 \\
(0.3433)\end{array}$ & $\begin{array}{c}0.5878 * * \\
(0.2605)\end{array}$ & $\begin{array}{l}-0.0580 * \\
(0.0327)\end{array}$ \\
\hline $\mathrm{X}_{7}$ & $\begin{array}{c}1.7969 \\
(3.4976)\end{array}$ & $\begin{array}{l}-7.2140^{*} \\
(4.1835)\end{array}$ & $\begin{array}{l}-0.6516 \\
(0.4903)\end{array}$ & $\begin{array}{c}15.0812 \\
(43.3153)\end{array}$ & $\begin{array}{c}-106.5775^{*} \\
(55.1499)\end{array}$ & $\begin{array}{l}-5.8935 \\
(4.4849)\end{array}$ & $\begin{array}{c}-38.2438 * * * \\
(10.1664)\end{array}$ & $\begin{array}{c}-24.7826 \\
(15.0313)\end{array}$ & $\begin{array}{c}1.7977 \\
(1.4606)\end{array}$ & $\begin{array}{l}-183.7308^{*} \\
(105.4788)\end{array}$ & $\begin{array}{l}-77.6114 \\
(80.0466)\end{array}$ & $\begin{array}{c}-5.2294 \\
(10.0449)\end{array}$ \\
\hline $\mathrm{X}_{13}$ & $\begin{array}{c}0.7741 \\
(2.6359)\end{array}$ & $\begin{array}{c}2.7086 \\
(3.1529)\end{array}$ & $\begin{array}{c}0.7993 * * \\
(0.3695)\end{array}$ & $\begin{array}{l}-1.5469 \\
(1.5126)\end{array}$ & $\begin{array}{l}-3.7759 * \\
(1.9259)\end{array}$ & $\begin{array}{l}-0.1318 \\
(0.1566)\end{array}$ & $\begin{array}{l}-0.7060 \\
(1.0146)\end{array}$ & $\begin{array}{c}-3.5882 * * \\
(1.5001)\end{array}$ & $\begin{array}{c}-0.6709 * * * \\
(0.1458)\end{array}$ & $\begin{array}{c}19.0462 \\
(15.1896)\end{array}$ & $\begin{array}{l}21.2584 * \\
(11.5272)\end{array}$ & $\begin{array}{l}2.5200^{*} \\
(1.4465)\end{array}$ \\
\hline $\mathrm{X}_{14}$ & $\begin{array}{c}1.5684 \\
(3.1123)\end{array}$ & $\begin{array}{c}5.6417 \\
(3.7228)\end{array}$ & $\begin{array}{c}0.8738^{* *} \\
(0.4363)\end{array}$ & $\begin{array}{l}4.2979^{*} \\
(2.4601)\end{array}$ & $\begin{array}{c}1.8436 \\
(3.1323)\end{array}$ & $\begin{array}{c}0.7029^{* * * *} \\
(0.2547)\end{array}$ & $\begin{array}{c}1.7080 \\
(1.1137)\end{array}$ & $\begin{array}{l}-2.2155 \\
(1.6466)\end{array}$ & $\begin{array}{c}-0.5072^{* * * *} \\
(0.1600)\end{array}$ & $\begin{array}{l}44.6584^{*} \\
(22.4928)\end{array}$ & $\begin{array}{l}32.8117^{*} \\
(17.0695)\end{array}$ & $\begin{array}{l}4.2446^{*} \\
(2.1420)\end{array}$ \\
\hline$X_{16}$ & $\begin{array}{c}3.7192 \\
(13.4378)\end{array}$ & $\begin{array}{c}6.4202 \\
(16.0732)\end{array}$ & $\begin{array}{c}1.8389 \\
(1.8839)\end{array}$ & $\begin{array}{c}2.3259 \\
(7.0972)\end{array}$ & $\begin{array}{c}36.4202 * * * \\
(9.0363)\end{array}$ & $\begin{array}{l}1.9327 * * \\
(0.7348)\end{array}$ & $\begin{array}{c}-6.2772 * * * \\
(1.7673)\end{array}$ & $\begin{array}{c}1.9802 \\
(2.6131)\end{array}$ & $\begin{array}{c}-1.0301 * * * \\
(0.2539)\end{array}$ & $\begin{array}{c}4.6084 \\
(73.4145)\end{array}$ & $\begin{array}{c}130.9069 * * \\
(55.7134)\end{array}$ & $\begin{array}{c}19.1224 * * \\
(6.9914)\end{array}$ \\
\hline $\mathrm{b}_{0}$ & $\begin{array}{l}-0.2661 \\
(2.2625)\end{array}$ & $\begin{array}{l}-4.0606 \\
(2.7062)\end{array}$ & $\begin{array}{c}-0.7017^{* *} \\
(0.3172)\end{array}$ & $\begin{array}{c}-0.4919 \\
(1.5038)\end{array}$ & $\begin{array}{c}0.1058 \\
(1.9147)\end{array}$ & $\begin{array}{c}0.1175 \\
(0.1557)\end{array}$ & $\begin{array}{l}-0.3703 \\
(0.6778)\end{array}$ & $\begin{array}{c}1.5325 \\
(1.0022)\end{array}$ & $\begin{array}{c}0.6728^{* * *} \\
(0.0974)\end{array}$ & $\begin{array}{l}-22.8208 \\
(17.4233)\end{array}$ & $\begin{array}{l}-26.7995^{*} \\
(13.2223)\end{array}$ & $\begin{array}{c}-4.0837^{* *} \\
(1.6592)\end{array}$ \\
\hline$N$ & 97 & 97 & 97 & 60 & 60 & 60 & 120 & 120 & 120 & 30 & 30 & 30 \\
\hline Adjusted $\mathrm{R}^{2}$ & 0.3606 & 0.4513 & 0.2151 & 0.3858 & 0.5255 & 0.5204 & 0.5504 & 0.4388 & 0.4864 & 0.3801 & 0.3823 & 0.3540 \\
\hline $\mathrm{F}$ & 8.7332 & 12.2793 & 4.7580 & 6.2943 & 10.3356 & 10.1445 & 21.8139 & 14.2903 & 17.0978 & 3.5407 & 3.5637 & 3.2700 \\
\hline Prob $>F$ & 0.0000 & 0.0000 & 0.0001 & 0.0000 & 0.0000 & 0.0000 & 0.0000 & 0.0000 & 0.0000 & 0.0106 & 0.0103 & 0.0155 \\
\hline
\end{tabular}


Table note:

(1) * indicates that $p$-value of the coefficient is in the range from 0.05 to $0.1, * *$ indicating a $p$-value of 0.01 to 0.05 , and $* * *$ with the $p$-value of less than 0.01 .

(2) And the number within the bracket is the standard error of the coefficient. 


\subsection{Discussion}

Based on the analysis results in Table 6 and Table 7, the following discussions are conducted for understanding how fire safety management is attended in its dramatic urbanization process in China at both national and regional level.

\subsubsection{How fire safety management is attended from the perspective of the number of fire $\left(\mathrm{Y}_{1}\right)$ during the urbanization process?}

\section{At national level}

As shown in Table 6, at national level, the performance of $Y_{1}$ (the number of fire) is significantly interrelated with urbanization variables $\mathrm{X}_{5}$ (the value of completed buildings), $\mathrm{X}_{7}$ (ratio of built-up urban areas) and $\mathrm{X}_{16}$ (proportion of education investment in GDP), where $\mathrm{X}_{5}$ has positive interrelationship whilst $\mathrm{X}_{7}$ and $\mathrm{X}_{16}$ have negative interrelationship. In other words, the increase of buildings can result in the increase of fire accidents, whilst the increase of built-up urban areas and the education investment can help the reduction of fire accidents in the Chinese urbanization process. The analysis results further indicate that the fire safety management performance has been reasonably attended at national level in China during implementing its urbanization programs from the perspective of fire number.

In fact, fire often happens in buildings. According to statistics, building fires are the most common and harmful ones among all kinds of fires. From 2010 to 2014, the direct economic loss induced by building fires accounted for about $80 \%$ of the total direct economic loss induced by fires. The number of building fires accounted for $60 \%$ 
of the total number of fires (Fire Department of the Ministry of Public Security of China, 2015). The most shocking fact is that the casualties in building fires accounted for more than $90 \%$ of the total number of casualties induced from fires (Fire Department of the Ministry of Public Security of China, 2015). Buildings are therefore commonly appreciated as the major battlefield of fire safety management in an urban area. Furthermore, with the rapid urbanization development, the number of high-rise and super-high-rise buildings in city is increasing dramatically, especially in urban central areas. These buildings have presented more fire risks, and the consequences from these risks are more severe.

However, the presence of fire safety risks in buildings is further intensified by typical problems, such as improper building planning and design without sufficient corporation of fire safety facilities (Zhuang and Shen, 2010; Li et al., 2005), obsolete technologies adopted in the process of building construction, the extensive use of flammable building materials (Li et al., 2005; Hui et al., 2012), the lack of knowledge and awareness on fire accidents among both construction workers and managerial staff (Hui et al., 2012). All these problems indicate that buildings are often the starting-points for fire accidents. In other words, the fire safety management performance in the context of buildings has overwhelming impacts on the fire safety management performance in urban area. Therefore, the efforts should be given to the improvement of fire safety facilities in buildings.

In referring to $\mathrm{X}_{7}$ (ratio of built-up urban areas), it has close relation with urban infrastructures which include fire safety facilities. And the quality of urban 
infrastructure associates closely with the level of fire safety management performance. As more built-up urban areas means that more fire safety facilities will be provided, the fire safety performance can be improved in line with the increase of built-up urban areas. There are mainly two types of buildings in built-up urban areas, namely, new and existing buildings. In China, it is considered that existing buildings need more infrastructures in order to improve fire safety management performance. Many of the existing buildings are designed and built under the old fire safety codes, and they have not upgraded the facilities according to new fire safety standards. For example, precast concrete slabs are widely used in multi-story buildings with reinforced concrete structures before $1990 \mathrm{~s}$, and the fire resistance capability of most existing buildings is even unable to meet the basic requirement of fire resistance according to new standards. Furthermore, the fire-resistance capability of existing buildings has decreased because of building aging and partial damage during the operation stage (Zhuang and Shen, 2012).

On the other hand, the interrelationship of $\mathrm{X}_{16}$ (proportion of education investment in GDP) and $\mathrm{Y}_{1}$ is negative at national level, as shown in Table 6. This indicates that the increase of education investment particularly on fire safety management will empower people's knowledge about fire safety management, and consequently help reduce the fire number. Actually, this negative relationship between education investment and fire accident is also echoed in previous studies (Jennings, 1996; Karter and Donner, 1978; Schaenman, 1977).

\section{At regional level}


However, at regional level, the fire safety management performance in terms of the fire numbers has been attended differently between regions, which is evidenced with different coefficient values. It can be seen from the analysis results in Table 7 that the interrelationships between urbanization variables and fire safety performance variables are different significantly between regions, although some similarities exist. In terms of the similarity, for example, the interrelationships between $\mathrm{X}_{5}$ (the value of completed buildings) and $\mathrm{Y}_{1}$ (the number of fire) in the Eastern and Western regions are both positive, which means that more completed building areas can induce a larger number of fires in these regions.

Nevertheless, significant differences exist between regions. For the case of $\mathrm{X}_{2}$ (urban population density), its interrelationship with $Y_{1}$ (the number of fire) is negative in Northeast region, as evidenced by the coefficient value of -4.5463 in Table 7. This indicates that the increase of urban population density contributes to the reduction of fire numbers in Northeast region. It further suggests that the number of fires will not increase even the urban population density increases if the fire safety management investment per capita or per unit of urban area is sufficient (Xia et al., 2017). In other words, the urban population density will not necessarily induce more fire risks if the urban population density is under a certain threshold. However, when the density excesses certain threshold, any population growth can induce the increase of fire numbers.

For the West China, according to the analysis result shown in Table 7, the performance of $\mathrm{Y}_{1}$ (the number of fire) is positively interrelated with urbanization 
variables $\mathrm{X}_{1}$ (population urbanization rate) and $\mathrm{X}_{5}$ (the value of completed buildings). But it has negative interrelationship with $\mathrm{X}_{7}$ (ratio of built-up urban areas) and $\mathrm{X}_{16}$ (proportion of education investment in GDP). This means that the increase of urban population does cause the increase of number of fires in West China. In fact, the increase of urban population is accompanied by more human activities, which in turn induce more fire hazards. The study by Li (2006) also shows that the intensification of population urbanization is one of the major causes of fire hazards.

In referring to $\mathrm{X}_{7}$, the analysis results in Table 7 indicate that the number of fires can be reduced significantly by increasing the built-up urban areas in West region. In fact, comparing to the other regions in the country, West China traditionally has lower level of fire safety management, thus any improvement of fire safety facilities can contribute to the reduction in fire numbers in this region. In fact, the West China has contributed good efforts in improving fire safety facilities during the urbanization process. According to the official statistics, the number of fire stations in West China has increased dramatically by $92.13 \%$ during 2005 to 2014, while this figure in East, Middle and Northeast China is relatively small, namely, $72.34 \%, 56.10 \%$ and $23.61 \%$ respectively (Fire Department of the Ministry of Public Security of China, 2015). The above information suggests that West China has achieved good progress in the aspect of improving fire facilities in line with the construction of more built-up urban areas during the urbanization process. This contributes to the decrease of fire numbers in this region. Furthermore, as shown in Table 7, the interrelationship between $\mathrm{X}_{16}$ (proportion of education investment in GDP) and $\mathrm{Y}_{1}$ (the number of fire) is negative 
in West region, suggesting that the increase of education investment can contribute to the reduction of fire accidents. The negative correlation between education investment and fire number has also been evidenced at national level, and this has been discussed in previous section.

\subsubsection{How fire safety management is attended from the perspective of the direct economic loss of fires $\left(\mathrm{Y}_{2}\right)$ during the urbanization process?}

\section{At national level}

It can be seen from Table 6 that at national level, fire safety management performance in terms of $\mathrm{Y}_{2}$ (the direct economic loss of fires) is positively associated with $\mathrm{X}_{2}$ (urban population density) and $\mathrm{X}_{5}$ (values of completed building), whilst negatively related to $\mathrm{X}_{7}$ (ratio of built-up urban areas). This shows that the direct economic loss from fire accidents can be reduced by decreasing the urban population density, reducing the values of completed building, and increasing the built-up urban areas.

In fact, the increase of $X_{2}$ (urban population density) mainly refers to the increase of population flow from rural to urban area. Most of those rural-to-urban migrants have received limited education and have been equipped with little fire safety knowledge. Some of their behaviors present fire risks, such as smoking in those non-smoking places and occupying the fire safety evacuation passages (Cai, 2004). Furthermore, these migrants are mainly engaged in labor-intensive jobs, and live in crowed buildings where the condition of fire safety facilities are usually very poor. This is why the increase of urban population density can result in the increase of 
direct economic loss from fires in almost all the cities in China. Similarly, the results indicate that the increase of $\mathrm{X}_{5}$ (values of completed building), has induced the increase of economic loss from fire accidents, and this has been discussed already in previous section.

However, for $\mathrm{X}_{7}$ (ratio of built-up urban areas), it has significant negative correlation with $\mathrm{Y}_{2}$ at national level, with the coefficient value of -6.3929 , as shown in Table 6. This indicates that the increase of built-up urban areas can lead to the reduction of economic loss from fire accidents. This phenomenon is largely because of the improvement of fire safety facilities in newly built-up urban areas. For example, the urbanization development has benefited significantly the increase of municipal fire hydrant number from 506,895 in 2005 to 984,500 in 2014 nationally (Fire Department of the Ministry of Public Security of China, 2015), with an increment of $94.2 \%$ during the decade.

\section{At regional level}

At regional level, there are both similarities and differences about the interrelationships between $X_{i}$ and $Y_{2}$ among regions. In referring to the similarity, for example, the interrelationship between $\mathrm{X}_{5}$ (values of completed building) and $\mathrm{Y}_{2}$ is positive across all the four regions in China with very similar coefficient values, as shown in Table 7. This analysis result indicates that the increase of completed buildings can lead to more economic loss from fire accidents across all the regions.

In another example, the interrelationship between $\mathrm{X}_{2}$ (urban population density) and $\mathrm{Y}_{2}$ is positive both in East and West China, evidenced by the coefficients of 
4.2698 and 0.7718 respectively in Table 7. However, it can be seen that East region enjoys much stronger correlation between the two variables than that in West China. East China is more advanced in terms of economic and social development level (with per capita GDP several times higher than that of other regions), thus this region has been receiving more inflowing migrants during the urbanization process. This has resulted in much higher urban population density in East region than that in the West China. As appreciated in previous section, the higher population density will cause more economic loss if fire accident occurs. This interprets that per unit increase of $\mathrm{X}_{2}$ (urban population density) in East China can bring much more direct economic loss of fire accidents than that in West China. This finding also shows that the control on $\mathrm{X}_{2}$ in East China can have more impacts on the decrease of economic loss if fire occurs than that in West China.

In the case of $\mathrm{X}_{16}$ (proportion of education investment in GDP), its interrelationship with $\mathrm{Y}_{2}$ is positive both in Central and Northeast China. This suggests that there is positive correlation between fire accidents and the level of education investment in these two regions. It is interesting to note that the increase of education investment would not help reduce the economic loss of fires, although it is generally considered that education investment can help improve the performance of fire safety management. This phenomenon is contributed by the fact that although the total education investment increases in these regions, the investment on fire safety education is very limited. In fact, compared with the developed countries, China has invested much less resources on fire safety education. For example, it was reported in 
the literatures that Japan had already over 50 fire engineering colleges by the year 2006 (Chen, 2006), whilst China had only less than 20 fire engineering colleges by the year 2015 (Wang, 2015) For another example, the Fire Service College (FSC) in UK, one of the top universities specialized in fire engineering worldwide, has been training 6,000 fire professionals per year for 75 countries, but there is no such professional training college in China (Chen, 2006). Therefore, it is considered that the Chinese government should contribute more investment in fire safety education.

However, according to Table 7, significant differences present among regions in terms of the interrelationship between $\mathrm{X}_{13}$ (GDP proportion of the second industry) and $Y_{2}$. The table tells that the interrelationship between $X_{13}$ and $Y_{2}$ is negative in West China, whilst there is no significant interrelationship in the other regions. It indicates that the increase of the GDP proportion by the secondary industry will lead to the reduction of direct economic loss of fires in the West China. This appears contradictory to the common knowledge that the increase of secondary industry would lead to the increase of fire accidents ( $\mathrm{Li}$ et al., 2006; Yang and Li, 2018). Nevertheless, the case is different in West China, which is relatively less developed (Shen et al., 2018). According to the statistics for the year 2016, the GDP per $\mathrm{km}^{2}$ land area in West China is 2.30 million Rmb, whilst that in East China is 44.79 million Rmb (National Bureau of Statistics of China, 2017). It is considered that any increase of secondary industry in West China will be accompanied with the advancement of urban infrastructure particularly fire facilities, which in turn will contribute to the reduction of fire loss. In fact, West China is defined as the major 
secondary industry base. The central government has invested amount of capitals to this region. For example, according to the official report, since the implementation of the western development strategy, a sum of 6 trillion and 850 billion Rmb has been invested to 317 key projects in West China from 2000 to 2017(Wen, 2018).

\subsubsection{How fire safety management is attended from the perspective of the number of fire casualties $\left(\mathrm{Y}_{3}\right)$ during the urbanization process?}

\section{At national level}

As shown in Table 6, at national level, the performance of $\mathrm{Y}_{3}$ (the number of fire casualties) is negatively correlated with urbanization variables $\mathrm{X}_{2}$ (urban population density) and $\mathrm{X}_{16}$ (proportion of education investment in GDP), whilst positively correlated with $\mathrm{X}_{5}$ (the value of completed buildings). In other words, the increase both in urban population density and education investment will help the reduction of fire casualties in the Chinese urbanization process, whilst the increase of completed buildings can induce more fire casualties. It indicates that the fire safety management performance from the perspective of fire casualty numbers can be improved at national level through controlling specific urbanization variables in China.

It is interesting to note that the increase in urban population density would not increase the fire casualties at national level. This could be due to the fact that fire facilities have been improved substantially in recent years across the country during urbanization process. For example, the number of fire stations in 2005 was 3,314 in China, while that was 5,509 in 2014, giving a growth rate of $66.23 \%$ in ten-year time period (Fire Department of the Ministry of Public Security of China, 2015). 
The interrelationship between $\mathrm{X}_{5}$ and $\mathrm{Y}_{3}$ is positively correlated. This correlation pattern is similar to the interrelationship between $\mathrm{X}_{5}$ and $\mathrm{Y}_{1}$, which has been discussed in Section 5.2.1. Furthermore, it has been found that the correlation pattern between $\mathrm{X}_{16}$ and $\mathrm{Y}_{3}$ is similar to that between $\mathrm{X}_{16}$ and $\mathrm{Y}_{1}$, which has also been discussed previously in Section 5.2.1.

\section{At regional level}

According to Table 7, the correlation between $\mathrm{X}_{1}$ (population urbanization rate) and $\mathrm{Y}_{3}$ (the number of fire casualties) is negative in Central China, whilst that correlation is not significant in other regions. This analysis result suggests that the increase of urban population does not induce the increase of fire casualties in Central China. This is due to the fact that fire-fighting efficiency has been improved in Central China. In fact, the fire-fighting efficiency is closely associated with various aspects such as the scale and quality of firemen, fire-fighting technologies and traffic conditions in urban area, as appreciated in previous study (Xiao et al., 2011). The fire-fighting capability in Central China is considered much better than that of the average capability across the country. Table 8 shows the comparison on fire-fighting capabilities between Central China and national average level for the year 2014, which demonstrates that the fire-fighting capability in Central China is much better than the national average level.

Table 8 The comparison of fire-fighting capabilities in Central China and national average 
Number of fire stations per $10,000 \mathrm{~km}^{2}$

Number of urban and rural fire brigades per 10,000 km2

Number of fire vehicles per $10,000 \mathrm{~km}^{2}$

Number of fire rescue equipment per $10,000 \mathrm{~km}^{2}$
11

18

66

687

Data source: Fire Department of the Ministry of Public Security of China (2015)

Table 7 further shows that the urbanization variable $\mathrm{X}_{5}$ (values of completed building) has a positive correlation with $\mathrm{Y}_{3}$ (the number of fire casualties) in the East, Central and West China. This correlation pattern is similar to the interrelationship between $\mathrm{X}_{5}$ and $\mathrm{Y}_{1}$ for East and West regions, and the implication of this correlation pattern has been discussed in Section 5.2.1.

However, the correlation patterns between $\mathrm{X}_{16}$ and $\mathrm{Y}_{3}$ varies considerably among regions. For example, this correlation is negative in West China, whilst that is positive in Central and Northeast China. This indicates that the increase of education investment does not induce the increase of fire casualties in West China, whereas that has brought the growth of fire casualties in Central and Northeast regions. West China is traditionally regarded as less developed both socially and economically with poor education infrastructure. It is considered any increment in education investment in West China will bring significant progress in multiple dimensions including fire safety management performance. In referring to Central and Northeast China, they have better education infrastructures. Therefore the increment of education investment in these regions has much smaller marginal effect. And this can explain why the 
increase of education investment does not necessarily help reduce fire casualties in these regions.

From Table 7, it can be seen that the correlation patterns of $\mathrm{X}_{13}$ (GDP proportion of the second industry) and $\mathrm{X}_{14}$ (GDP proportion of the third industry), with $\mathrm{Y}_{3}$ (the number of fire casualties) are significantly different between regions. For example, $\mathrm{X}_{14}$ has a positive correlation with $\mathrm{Y}_{3}$ in East and Central China, whilst the correlation pattern for West China is negative. This indicates that the increase of tertiary industry can induce the increase of fire casualties in East and Central China, whilst that contributes to the reduction of fire casualties in West China. It is well appreciated that the development of tertiary industry is driven by service industries such as hotels, entertainments and shopping malls. These services are commonly characterized with large scale of population aggregation, which presents higher risks of fires and fire casualties (Xia et al., 2017; Chen et al., 2006). The tertiary industry in East and Central China is much advanced in comparing to West China, this explains why the increase of GDP proportion of tertiary industry can induce the increase of the number of fire casualties in East and Middle China. Nevertheless, as West China is much less developed both economically and socially, any growth in both secondary and tertiary industries can promote the development of urban infrastructures including fire safety facilities. Therefore, the increase of GDP proportion of tertiary industry will not induce the increase of fire casualties in West China.

\section{Conclusion}


This study has investigated how fire safety management is attended during the urbanization process in China. The main findings can be highlighted as follows. Firstly, the increase of urbanization rate and urban population density has caused to considerable extend the increase of urban fire hazards during the dramatic urbanization process in China. Secondly, buildings are the major sources to urban fires, evidenced by the positive correlation between the value of completed urban buildings and urban fires at both national and regional level in China. Thirdly, education investment has different effects on the performance of fire safety management between different regions in China. For example, in West region, the increase of education investment has contribution to the reduction of fire casualties, whilst that has induced to the growth of fire casualties in Central and East region. Fourthly, the economic structure also has different effects on the performance of fire safety management between regions in China. For example, in West region, the growth of tertiary industry has contributions to the reduction of the direct economic loss of fires, whilst that has induced to the growth of direct economic loss of fires in East region.

By appreciating the above findings, the following policy recommendations can be proposed in order to enhance the performance of fire safety management in the Chinese urbanization process.

First of all, both central and local governments should introduce policy measures for improving the fire safety consciousness among urban residents. For example, fire prevention training programs should be provided particularly in those densely 
populated urban areas. Previous studies have appreciated that training is a very effective approach to improve fire safety performance ( $\mathrm{Si}, 2014$; Cai, 2004). Regulations should be introduced to guide public communities' behaviors towards fire safety. It was reported in a number of existing studies that changing public's behaviors is an effective approach for improving fire safety management performance in the cities such as Hong Kong and Taipei (Chien et al., 2013; Chow, 2001; Chow, 2002). Furthermore, compliance with fire safety regulations should be enforced in urban production activities. It was reported in previous studies that many fire accidents happened during the production process in factories or construction sites (Baum and McGrattan, 2000; Deng and Qiu, 2007). According to statistics, the direct economic loss of fires in production process in 2014 in China accounted for $13.1 \%$ of the total fire-related economic loss (Fire Department of the Ministry of Public Security of China, 2015). It is therefore considered essential to implement strict fire safety regulations in the process of urban production activities.

Secondly, policy measures should be introduced to improve buildings' fire-resistance function. As addressed earlier in this paper that various types of urban buildings present higher risks of fire accidents, including residential buildings, hotels, offices, theaters, and shopping malls. For example, Li et al. (2005) and Zhuang et al. (2010) pointed out that many building fires are caused by improper building design in the urbanization process in China. It is therefore considered important to incorporate fire safety management in the process of building planning and design. In fact, this is echoed in previous studies that improving the quality of building planning and design 
is a pressing issue for improving the performance of fire safety management (Zhang, 2010; Zhuang et al., 2010; Li et al., 2005). Furthermore, the application of advanced construction technologies for buildings is also important for improving the performance of building fire safety management. For example, Wang et al. (2015) pointed out that the application of building information modeling (BIM) can effectively improve the performance of building fire safety management. Supervision measures should also be imposed on the application of building materials particularly those inflammable materials such as plastics and timber during the construction process. The study by Cheng and Wang et al. (2011) shows that many construction fires are induced by improperly using inflammable building materials. During the occupation of buildings, fire safety regulations must be imposed to ensure that users do not change buildings' functions and structures. According to previous studies (Villeneni and Yu, 2017; Zhuang et al., 2010), it happens that many building users often change illegally the structures and functions of buildings, which has triggered many building fires. Regular inspection schedule should be conducted on fire safety facilities during the occupation of buildings. In fact, there is significant lack of annual inspection and maintenance schedule for fire safety facilities in China. Many building fires are caused by the obsolescence of fire facilities. In studying the fire facility inspection in the context of Hennan province in China, Niu and Xie (2011) found that only $55.1 \%$ fire facilities have been inspected annually, and only $41 \%$ fire safety facilities are in good condition. It is important therefore to ensure that the fire 
safety facilities are always in good conditions through regular inspections in order to mitigate the consequence of fires once they happen.

Thirdly, the Chinese urbanization process is typical characterized with the development of secondary and tertiary industries. The development of secondary and tertiary industries is normally accompanied with more urban fire risks. Local governments should take actions to provide sufficient fire safety measures in line with the development of secondary and tertiary industries, such as increasing the number of fire stations, increasing the number of firemen and fire professionals, updating fire safety facilities. These measures are also appreciated in previous studies, for example, Winter and Fried (2000), Wang et al. (2008), Lampin-Maillet et al. (2010). Li (2017), Tian (2017), and Zhang (2018).

Education wise, both central and local governments should invest more resources on fire safety education. In fact, China has been increasing the education investment in recent years, however the investment on fire safety education has not been properly addressed. Governments should consider to increase more professional colleges with specialism of fire safety management. The fire safety knowledge should be merged into students' curriculums, such as improving their fire safety consciousness by various teaching activities. And more fire drills should be practiced in schools to help young generations know how to protect and rescue themselves in case of fires (Yu et al., 2012).

Considering the differences between regions, it is recommended that tailor-made policies or measures should be designed for different regions by referring to their 
local backgrounds and their fire safety circumstances. Without this consideration, some policy measures may not be applicable or effective. For example, those Northern cities where the winter is very cold can only use dry-sprinkle fire safety system, whilst those Southern cities where most of the time is hot weather can employ either wet or dry sprinkle fire safety system (Xiao, 2013). For another example, those densely populated cities such as Shanghai and Guangzhou should establish more fire stations. This approach can ensure that fire safety management performance can be improved in all regions in the country. Consequently, the sustainability of urbanization development in the context of China can be achieved.

The findings of this study contribute to the development of the literation in the research discipline of fire safety management particularly in the context of urbanization process. The research framework designed in this study can be further applied to understand how fire safety management is attended in the other countries where the urbanization process is actively on-going. Practically, the research findings provide valuable references for decision makers of both central and local governments to formulate effective strategies and policies for improving the performance of fire safety management in China. By implementing these strategies and policies, not only the urban fire safety management performance can be improved, but also the sustainability of urbanization practice can be gained throughout the country.

The limitations of this study are appreciated. The indicators used for measuring the performance of fire safety management are limited due to the difficult accessibility of research data. Secondly, this study has not conduced the panel regression analysis 
because of the small volume of research data collected. And panel regression analysis is recommended for further study to examine the correlation between urbanization variables and fire-safety management performance. Thirdly, the experiences from those better fire safety performers and the lessons from those poor performers can be investigated in further studies.

\section{Acknowledgement}

This research was funded by National Social Science Foundation of China, grant number 17ZDA062 and 15BJY038.

\section{Reference}

Baum, C. F., \& Christopher, F. (2006). An introduction to modern econometrics using Stata. Stata press.

Baum, H. R., \& McGrattan, K. B. (2000). Simulation of large industrial outdoor fires. Fire Safety Science, 6, 611-622. (DOI: 10.3801/IAFSS.FSS.6-611)

Cai C.Y. (2004), On the renewed awareness of man's from prevention fire conflagrations, Journal of The Armed Police Academy,2004, No. 2.

Chan, K. W., Hu, Y. (2003). Urbanization in China in the 1990s: New definition, different series, and revised trends. China Review, 49-71. (https://www.jstor.org/stable/23461904)

Chen F.G., Zhang H.O., Wu Q.T., Chen W.L. (2010), A Study on Coordinate Development Between Population Urbanization and Land Urbanization in China,Human Geography Vol.25 No.5 2010/10.

(DOI:10.13959/j.issn.1003-2398.2010.05.007)

Chen L, \& Wang G.Y. (2011). Research on fire safety management of building decoration project from the occurrence of two major fire accidents. Urban roads bridges \& flood control (9), 165-166. (DOI: 10.3969/j.issn.1009-7716.2011.09.066)

Chen Z.F., Chen Jin, Huang C.F., Li Qiang, Tan M.Y. (2006), Fire risk assessment index system for large-scale public places(I): causality analysis for fire accident, Journal of Natral Disasters, Vo.l 15, No. 1. (DOI:10.3969/j.issn.1004-4574.2006.01.012)

Chen Z.J., Wang F.L., Lu S.X., Fang Z.B. (2007), Cluster Analysis of Fire Data in China, Engineering Science, Jan. 2007 Vol.9 No.1. (DOI:10.3969/j.issn.1009-1742.2007.01.017)

Chen, M. X., Lu, D. D., \& Zhang, H. (2009). Comprehensive evaluation and the driving factors of China's urbanization. Acta Geographica Sinica, 64(4), 387-398. 
(DOI: 10.3321/j.issn:0375-5444.2009.04.001)Chen Shi (2006), Fire education of overseas, science and technology of west China, No. 2.

Chien, S., Chen, Y., Lin, C., Shen, T., \& Huang, P. (2013). Upgrading fire safety strategies for the existing non-residential occupancies in Taipei City. Procedia Engineering, 62, 1096-1103. (DOI: 10.1016/j.proeng.2013.08.166)

China Fire Yearbook (2005 - 2015), Fire Department of the Ministry of Public Security of China, Yunnan Publishing Group

China Statistical Yearbook (2005-2014), National Bureau of Statistics of China, available at http://www.stats.gov.cn/tjsj/

Chines Government Report, 2016, available at www.scio.gov.cn/ztk/dtzt/34102/34261/34265/Document/1471601/1471601_1.h tm

Chow, W. K. (2001). Review on fire safety management and application to Hong Kong. International Journal on Engineering Performance-Based Fire Codes, 3(1), 52-58.

Chow, W. K. (2002). Proposed fire safety ranking system EB-FSRS for existing high-rise nonresidential buildings in Hong Kong. Journal of architectural engineering, 8(4), 116-124. (https://doi.org/10.1061/(ASCE)1076-0431(2002)8:4(116))

Cohen, P., West, S. G., \& Aiken, L. S. (2014). Applied multiple regression/correlation analysis for the behavioral sciences. Psychology Press. (DOI: https://doi.org/10.4324/9781410606266)

Crippa, P., Castruccio, S., Archer-Nicholls, S., Lebron, G. B., Kuwata, M., Thota, A., ... \& Spracklen, D. V. (2016). Population exposure to hazardous air quality due to the 2015 fires in Equatorial Asia. Scientific reports, 6, 37074.

CSMAR Research Data Service, available at http://www.gtarsc.com/Home\#

Deng Y.Y., Qiu C.H. (2007), City Industry Fire Risk Assessment, China Public Security, No.03. (DOI:10.3969/j.issn.1672-2396.2007.03.010)

Dong Yi, Chang Ning, Liu M.Y. (2015), The Multiple Correlation Analysis between the Characterization Factors of New Urbanization Level and 4 Fire Indicators, Fire Science and Technology, Vol.34 No.7 July 2015.(DOI: 10.3969/j.issn.1009-0029.2015.07.034).

Du Lanping et al. (2002), Fire safety situation, gaps and Countermeasures in China, Fire Science and Technology, September 2002, No.5.

(DOI:10.3969/j.issn.1009-0029.2002.05.001)

Ezekiel, M. (1930). Methods of correlation analysis. Oxford, England: Wiley.

Ezekiel, M., \& Fox, K. A. (1959). Methods of correlation and regression analysis: Linear and curvilinear(3rd ed.). Oxford, England: John Wiley.

Gao R.X. et al. (2007), Statistical analysis of fire losses in the US in 2005, Fire Technique and Products Information, 2007, No. 6.

(DOI:10.3969/j.issn.1002-784X.2007.06.026)

Guan, X., Wei, H., Lu, S., Dai, Q., \& Su, H. (2018). Assessment on the urbanization strategy in China: Achievements, challenges and reflections. Habitat 
International, 71, 97-109. (https://doi.org/10.1016/j.habitatint.2017.11.009)

Guo, F., Li, C., Chen, C., \& Gan, J. (2015). Spatial-temporal coupling characteristics of population urbanization and land urbanization in northeast China. Econ. Geogr, 35, 49-56. (DOI: 10.15957/j.cnki.jjdl.2015.09.007)

Hayasaka, H., Noguchi, I., Putra, E. I., Yulianti, N., \& Vadrevu, K. (2014). Peat-fire-related air pollution in Central Kalimantan, Indonesia. Environmental pollution, 195, 257-266. (https://doi.org/10.1016/j.envpol.2014.06.031)

He X. Q., Min S.Q. (2014). Applied regression analysis. Fudan University Press. (ISBN: 9787040395532)

Hou S.Q. (2011). Research on relativity between environmental factors and landscape pattern indexes of urban fringe area in small scale. China Population Resources \& Environment.

Hui, L., Yongqing, W., Shimei, S., \& Baotie, S. (2012). Study on safety assessment of fire hazard for the construction site. Procedia Engineering, 43, 369-373. (DOI: 10.1016/j.proeng.2012.08.064)

Ignatavièius, G., Sakalauskienë, G., \& Oškinis, V. (2006). Influence of land fires on increase of heavy metal concentrations in river waters of Lithuania. Journal of Environmental Engineering and Landscape Management, 14(1), 46-51. (https://doi.org/10.1080/16486897.2006.9636878)

Ince, C. D., \& Aslan, B. (2019). Monitoring the Effects of Land Sizes on Private Property Transformation in an Urban Regeneration Project by Regression Analysis: Erenler Cedit Case Study, Kocaeli. Sustainable Cities and Society, 101632. (https://doi.org/10.1016/j.scs.2019.101632)

Jennings C R. (1996), Urban residential fires: an empirical analysis of building stock and socioeconomic characteristics for Memphis. Tennessee, 1996.

Karter, M. J., \& Donner, A. (1978). The effect of demographics on fire rates. Fire Journal, 72(1), 53-65.

Gunther, P. (1980). Fire cause patterns for different socio-economic neighborhoods in Toledo, Ohio. FEMA.

L.Z. Yang, D.B. Jiang (2003), The Relationship Between Fire and Socioeconomic Factors in China, Engineering Sciences, Feb. 2003 Vol.5 No.2. (DOI: 10.3969/j.issn.1009-1742.2003.02.010)

Lampin-Maillet, C., Jappiot, M., Long, M., Bouillon, C., Morge, D., \& Ferrier, J. P. (2010). Mapping wildland-urban interfaces at large scales integrating housing density and vegetation aggregation for fire prevention in the South of France. Journal of environmental management, 91(3), 732-741.

(https://doi.org/10.1016/j.jenvman.2009.10.001)

Li Jian (2017), Fire safety status and fire prevention measures of high-rise buildings, Technology Wind, No. 26, 101-101. (DOI:

10.19392/j.cnki.1671-7341.201726088)

Li Jing, Chen L.Z., Long X.M. (2005), Hidden troubles of existing buildings and fault tree analysis method, Industrial Construction, Vol.35, Supplement, 2005. (DOI: 10.13204/j .gyjz2005.s1.017)

Li Shu, Lu Z.H., Chen Ying, Zhang Z.Y., Luo Li (2005), An analyse of relation 
between economy development and fire accident, Fire Science and Technology, July 2005, Vol 24, No.4

Li Shu, Lu Z.H., Tang C.G., Liu Li, Yang Z.G. (2006), An analysis of the influence of the urbanization of fire accident, Fire Science and Technology, May 2006, Vol 25, No.3

Li Xin, Wen Jing, Lin Jian (2012), Review of Research on Land Urbanization and Related Studies, Progress in Geography, Vol.31, No.8. (DOI: 10.11820/dlkxjz.2012.08.007)

Li, Y. S., Zeng, Z. X., Zhang, M., \& Yu, S. J. (1999). Application of primary component analysis in the methods of comprehensive evaluation for many indexes. Journal of Hebei University of Technology, 1(28), 94-197.

(DOI:10.3969/j.issn.1007-2373.1999.01.022)

Liu C.J., Zhen L.Y. (2004), Urbanization and Sustainable Development of Urban and Rural Areas, The Science Publishing Company. (ISBN: 7-03-012525-8)

Lizhong, Y., Xiaodong, Z., Zhihua, D., Weicheng, F., \& Qing'an, W. (2002). Fire situation and fire characteristic analysis based on fire statistics of China. Fire safety journal, 37(8), 785-802. (DOI: 10.1016/s0379-7112(01)00054-6)

Lv Ping, Zhou Tao, Zhang Z.F., Tian Zhuo (2008), Construction and Application of Land Urbanization and Corresponding Measurement Index System, China Land Science, Vol.22 No.8, Aug. 2008. (DOI:10.3724/SP.J.1011.2008.00534)

Lv, T. G., Wu, C. F., Li, H. Y., You, H., \& Cai, X. (2016). The coordination and its optimization about population and land of urbanization: a case study of Nanchang city. Scientia Geographica Sinica, 36(2), 239-246. (DOI:

10.13249/j.cnki.sgs.2016.02.010)

Maitra, S., \& Yan, J. (2008). Principle component analysis and partial least squares: Two dimension reduction techniques for regression. Applying Multivariate Statistical Models, 79, 79-90.

Marlair, G., Simonson, M., \& Gann, R. G. (2004, July). Environmental concerns of fires: Facts, figures, questions and new challenges for the future. In 10.

International Interflam Conference (pp. 325-337). Interscience communications. London.

Mathieu, R., Pouget, M., Cervelle, B., \& Escadafal, R. (1998). Relationships between satellite-based radiometric indices simulated using laboratory reflectance data and typic soil color of an arid environment. Remote sensing of environment, 66(1), 17-28.

Migrant Population Service Center, National Health Commission, P.R. China, 2017, available at: www.chinaldrk.org.cn/wjw/\#/data/classify/population

News on Baidu, 2015, available at https://baike.baidu.com/item/8.12 天津滨海 新区爆炸事故/18370029?fr=aladdin

News on China Sohu Media; available at http://www.sohu.com/a/211159544_436021

News on Phoenix New Media, 2018, available at 
https://finance.ifeng.com/a/20180903/16483696_0.shtml

Niu, H. Y., Wu, Q., H., \& Chen, X., G. (2007). Correlation of Pollutants in SIIrfa $\infty$ Sediments in Guangzhou Section of Pearl River. Environmental Science \& Technology, 30(z1). (DOI:10.3969/j.issn.1003-6504.2007.z1.016)

NIU, S. J., \& XIE, X. Z. (2011). Analysis on current status, problems and countermeasures of building fire facilities. Journal of Safety Science and Technology, 9, 030. (DOI: 10.3969/j.issn.1673-193X.2011.09.027)

Ovadnevaitè, J., Kvietkus, K., \& Maršalka, A. (2006). 2002 summer fires in Lithuania: impact on the Vilnius city air quality and the inhabitants health. Science of the Total Environment, 356(1-3), 11-21. (https://doi.org/10.1016/j.scitotenv.2005.04.013)

Qi, X. X., Yang, Y. W., Yang, Z. Y. (2014). Research on the evaluation indicators of new-type urbanization. Macroeconomic Management, No.2(5), 1-54. (DOI:10.19709/j.cnki.11-3199/f.2014.02.018)

Ren, Y., Li, H., Shen, L., Zhang, Y., Chen, Y., \& Wang, J. (2018). What Is the Efficiency of Fast Urbanization? A China Study. Sustainability, 10(9), 3180. (https://doi.org/10.3390/su10093180)

Report on Baidu, available at https://baike.baidu.com/item/\%E6\%B6\%88\%E9\%98\%B2\%E5\%B7\%A5\%E7\%A8\%8 B\%E4\%B8\%93\%E4\%B8\%9A/2639122?fr=aladdin

Schaenman, P. S. (1977). Procedures for improving the measurement of local fire protection effectiveness. Urban Institute Press.

Shen, J. (2006). Understanding dual-track urbanisation in post-reform China: conceptual framework and empirical analysis. Population, Space and place, 12(6), 497-516. (https://doi.org/10.1002/psp.426)

Shen, L., Chen, Y., Li, H., Wei, X., \& Ren, Y. (2018). Development orientations for attracting investments-A perspective of less-developed townships in China. Cities, 76, 84-95. (https://doi.org/10.1016/j.cities.2018.01.011)

Shen, L., Ren, Y., Xiong, N., Li, H., \& Chen, Y. (2018). Why small towns cannot share the benefits of urbanization in China?. Journal of Cleaner Production, 174, 728-738. (https://doi.org/10.1016/j.jclepro.2017.10.150)

Si Ge, National Commission on Fire Prevention and Control (U.S.) (2014), America Burning, Peking University press. (ISBN:9787301242803)

Song X.Y. (2006), Discussion on fire safety during urbanization process, Fire Science and Technology, November 2006, Vol 25, No.6

Svendsen, C., Meharg, A. A., Freestone, P., \& Weeks, J. M. (1996). Use of an earthworm lysosomal biomarker for the ecological assessment of pollution from an industrial plastics fire. Applied Soil Ecology, 3(2), 99-107. (https://doi.org/10.1016/0929-1393(95)00085-2)

Tian M.G. (2017), Analysis of fire prevention strategy in public places, New Technology \& New Products of China, No. 11. (DOI:10.13612/j.cnki.cntp.2017.22.084)

Villeneni Angelo, Yu Z.S. (2017), Inspiration from GE building fires -- changes 
in building uses and upgrading of fire-fighting systems, Modern Occupational Safety, No.4, 83-85.

Wang J H,Sun J H, LO S M, Gao L.J., Yuen R.K.K.(2011), Statistical Analysis on the Temporal-spatial Characteristics of Urban Fires Under Typical Urbanization Features, Procedia Engineering, 11 (2011) 437-444.

(https://doi.org/10.1016/j.proeng.2011.04.680)

Wang J.Y., Wang Tao, Li B.G. (2008), Research on Fire-proof Monitored Control System of Modern City Buildings, Building Science, Vol.24, No.7. (DOI: 10.3969/j.issn.1002-8528.2008.07.027)

Wang, H., \& Fan, W. (1997). Progress and problems of fire protection in China. Fire Safety Journal, 28(3), 191-205. (https://doi.org/10.1016/S0379-7112(97)00007-6)

Wang, J., Shen, L., Ren, Y., Ochoa, J. J., Guo, Z., Yan, H., \& Wu, Z. (2019). A lessons mining system for searching references to support decision making towards sustainable urbanization. Journal of Cleaner Production, 209, 451-460. (https://doi.org/10.1016/j.jclepro.2018.10.244)

Wang, L M. (2015). The condition and development of fire safety professional education. Fire Technique and Products Information, No.(11), 68-70.

Wang, S. H., Wang, W. C., Wang, K. C., \& Shih, S. Y. (2015). Applying building information modeling to support fire safety management. Automation in Construction, 59, 158-167. (https://doi.org/10.1016/j.autcon.2015.02.001)

Wen, Z., (2018). The total investment in the development of the western region has reached 6.85 trillion yuan. China Tendering, No.1, 16-17.

Winter, G., \& Fried, J. S. (2000). Homeowner perspectives on fire hazard, responsibility, and management strategies at the wildland-urban interface. Society \& Natural Resources, 13(1), 33-49. (https://doi.org/10.1080/089419200279225)

Word Bank Open Data, 2018, available at: https://data.worldbank.org/

World Fire Statistics Report, National committees CTIF of Russia, Germany, USA, available at http://www.ctif.org

Wu C.P., Wang S.Y., Liu G.N. (2001), Cluster Analysis on Fires Occurred in China, Lit \& Inf Prev Med, Feb. 2001, Vol.7, No.1. (DOI:

10.3969/j.issn.1672-9153.2001.01.003)

Xia Z.L., Li Hao, Chen Y.H. (2017), Temporal and spatial distribution of urban fire events and mining of association rules, Fire Science and Technology, October 2017. Vol 36, No 10,123-127. (DOI: CNKI:SUN:XFKJ.0.2017-10-038).

Xia, C., Zhang, A., Wang, H., \& Yeh, A. G. (2019). Predicting the expansion of urban boundary using space syntax and multivariate regression model. Habitat International, 86, 126-134. (https://doi.org/10.1016/j.habitatint.2019.03.001)

Xiao Feng (2011), Study on improving the efficiency of fire-fighting and rescue in different regions, Science \& Technology Association Forum, No.1. (DOI: 10.3969/j.issn.1007-3973.2011.01.073)

Xiao, W. (2013). Selection of non-heating space sprinkler system in cold regions. Architecture \& Culture. No.10 (DOI: 10.3969/j.issn.1672-4909.2013.10.488)

Yang Anni, LI J.Z. (2018), Study on Evaluation Index System of Coal Mine Safety Based on AHP and Entropy Method, Coal Technology, Vol.37, No.07. (DOI: 


\subsection{1/j.cnki.ct.2018.07.124)}

Yang Y.S., Wu L.Z., Luo Y.R. (2006), Grey relation analysis on fire rates and socioeconomic factor, Fire Science and Technology, Vol 25, No.4.

Yu Q.Y., Zhou L. X., Yang J., Dai D.N., \& Li J. (2012). Quantitative analysis of fire emergency evacuation of pupils. Journal of Safety Science and Technology, No.7, 73-77. (DOI:10.3969/j.issn.1673-193X.2012.07.014)

Yue C. J. (2003). The influence of regional economic development differences on the allocation of educational resources. Education\& Economy, No.(1), 35-41. (DOI: 10.3969/j.issn.1003-4870.2003.01.009) Zhang L.J. (2018), Fire Risk Analysis and Fire Prevention Countermeasures of Large Commercial Complex, Fire Technique and Products Information, Vol.31, No.7.

Zhang J. M. (2010). Discussion on Fire Safety Management and Fire Fighting Countermeasures of High-rise Buildings under Construction from "11·15" Shanghai Teacher's Apartment Fire. Fire Technique and Products Information, No.12, 38-46. (DOI: 10.3969/j.issn.1002-784X.2010.12.012)

Zhang, Y., Shen, L., Shuai, C., Tan, Y., Ren, Y., \& Wu, Y. (2019). Is the low carbon economy efficient in terms of sustainable development? A global perspective. Sustainable Development, 27(1), 130-152. (https://doi.org/10.1002/sd.1884)

Zhou S.Z. (2013). Establishment of the indicator system of urbanization rate. Statistics and Management, No.4,133-134. (DOI:

10.3969/j.issn.1674-537X.2013.04.054)

Zhuang Y.J., Shen Bei (2010), Analysis of problems in existing building renovation fire design, Fire Science and Technology, November 2010, Vol 29, No.11. (DOI: 10.3969/j.issn.1009-0029.2010.11.011) 